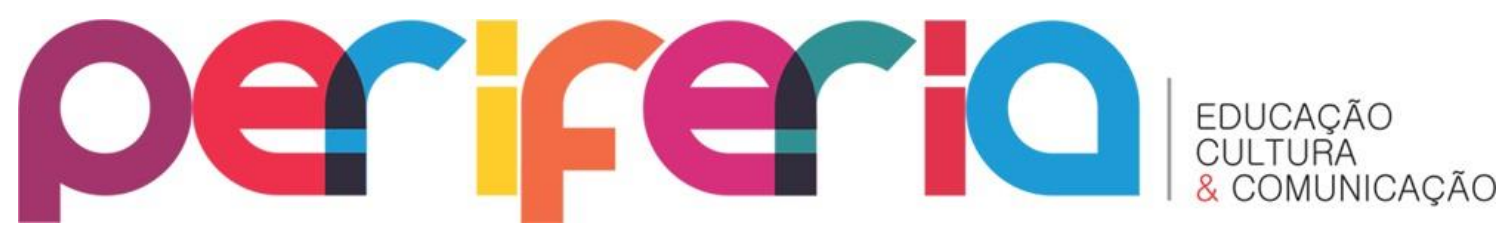

\title{
COMO AS FESTAS DE TERREIRO AJUDARAM A CONSTRUIR O PRESTÍGIO E O STATUS DO REI DO CANDOMBLÉ JOÃOZINHO DA GOMÉIA ENTRE SALVADOR E DUQUE DE CAXIAS (1948-1971)1
}

Andrea dos Santos Nascimento ${ }^{2}$

\section{Resumo}

João Alves Torres Filho foi o nome civil do pai de santo Joãozinho da Gomeia, que construiu uma trajetória de sucesso no panteão das religiões afro-brasileiras entre 1948 e 1971. O inicio deste caminho se dá em Salvador, onde era conhecido pelo nome de João da Pedra Preta em função do nome do caboclo que o inseriu nos mistérios do candomblé e o transformou em uma aclamada liderança afro-religiosa. 0 intuito deste artigo é apresentar parte do projeto de ascensão social de Pai João centrado nas festas que aconteciam no terreiro de São Caetano (Salvador) e Duque de Caxias na Baixada Fluminense. Eram festas especificas para lansã, Obaluaê, Oxossi; para o Caboclo Pedra Preta e festas de saídas de laôs, onde o pai de santo negociava status, poder e prestígio com chefes de polícia, delegados, militares de alta patente, políticos influentes, artistas, gente do café soçaite carioca, lideranças candomblecistas e chefes de tendas umbandistas. Por meio desta análise podemos exemplificar como Pai João construiu um Império religioso chamado Gomeia, e como a imprensa dá visibilidade a este Império, transformando-o em Tata Londirá, uma realeza do panteão afro-religioso.

Palavras-chaves: Festas de Terreiro; Joãozinho da Gomeia; Duque de Caxias; Salvador

\section{HOW THE TERREIRO PARTIES HELPED BUILD THE PRESTIGE AND STATUS OF THE KING OF CANDOMBLÉ JOÃOZINHO DA GOMÉIA BETWEEN SALVADOR AND DUQUE DE CAXIAS}

\section{Abstract}

João Alves Torres Filho was the civil name of the priest Joãozinho da Goméia who built a successful career in the pantheon of Afro-Brazilian religions between 1936

\footnotetext{
1 O corte temporal inicial (1948) deste artigo refere-se ao período em que as festas do terreiro da Goméia começaram a ser divulgadas na imprensa.

${ }^{2}$ Mestranda em Historia pelo Programa de Pos-Graduação em História da Universidade Federal Fluminense (UFF). ORCID iD: https://orcid.org/0000-0001-8045-9679. E-mail: deyanascimento.9@gmail.com
}

Periferia, v. 12, n. 3, p. 67-93, set./dez. 2020 


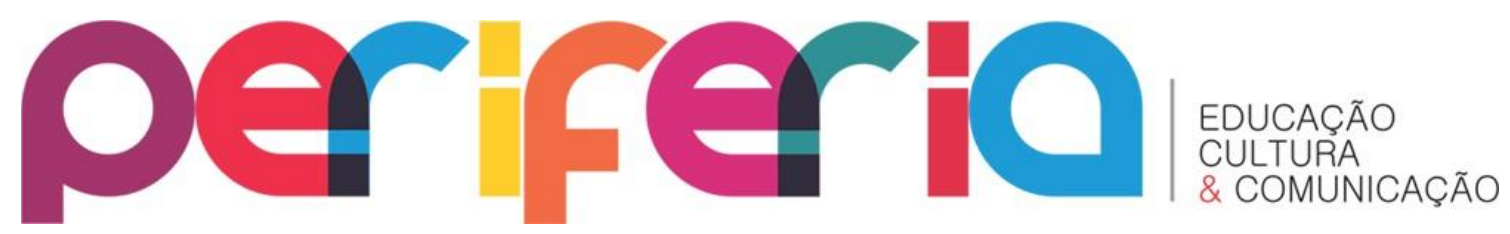

ISSN:1984-9540

DOI: $10.12957 /$ periferia.2020.54835

and 1971. The beginning of this path takes place in Salvador where he was known by the name of João da Pedra Preta for the caboclo that inserted him into the mysteries of Candomblé and transformed him into an acclaimed Afro-religious leadership. The purpose of this article is to present part of the project of social ascension of Pai João focused on the festivities that took place in the terreiro de São Caetano (Salvador) and Duque de Caxias in Baixada Fluminense. There were specific parties for lansã, Obaluaê, Oxossi; for the Caboclo Pedra Preta, where Pai de Santo negotiated status, power and prestige with policemen, delegates, highranking military, influential politicians, artists, people of the "café soçaite" carioca, candomblécista leaders and umbandista store leaders. Through this analysis, we can exemplify how the priest João built a religious empire called Goméia, and how the press gives visibility to this Empire by transforming it into Tata Londirá, a royalty of the Afro-religious pantheon.

Keywords: Terreiro Parties; Joãozinho da Gomeia; Duque de Caxias; Salvador

\section{CÓMO LAS FIESTAS TERREIRO AYUDARON A CONSTRUIR EL PRESTIGIO Y EL ESTATUS DEL REY DEL CANDOMBLÉ JOÃOZINHO DA GOMÉIA ENTRE SALVADOR Y DUQUE DE CAXIAS}

\section{Resumen}

João Alves Torres Filho era el nombre civil del sacerdote Joãozinho da Goméia que construyó una exitosa carrera en el panteón de las religiones afrobrasileñas entre 1936 y 1971. El inicio de este camino tiene lugar en Salvador donde fue conocido con el nombre de João da Pedra Preta por el caboclo que lo insertó en los misterios del Candomblé y lo transformó en una aclamada dirección afro-religiosa. El propósito de este artículo es presentar parte del proyecto de ascensión social de Pai João centrado en las festividades que tuvieron lugar en el terreiro de São Caetano (Salvador) y Duque de Caxias en Baixada Fluminense. Hubo fiestas específicas para lansã, Obaluaê, Oxossi; para el Caboclo Pedra Preta, donde Pai de Santo negociaba estatus, poder y prestigio con policías, delegados, militares de alto rango, políticos influyentes, artistas, gente del "café soçaite" carioca, líderes candomblécistas y líderes de tiendas umbandistas. A través de este análisis podemos ejemplificar cómo el sacerdote João construyó un imperio religioso llamado Goméia, y cómo la prensa da visibilidad a este Imperio transformándolo en Tata Londirá, una realeza del panteón afro-religioso.

Palabras-claves: Fiestas del Terreiro; Joãozinho da Gomeia; Duque de Caxias; Salvador 


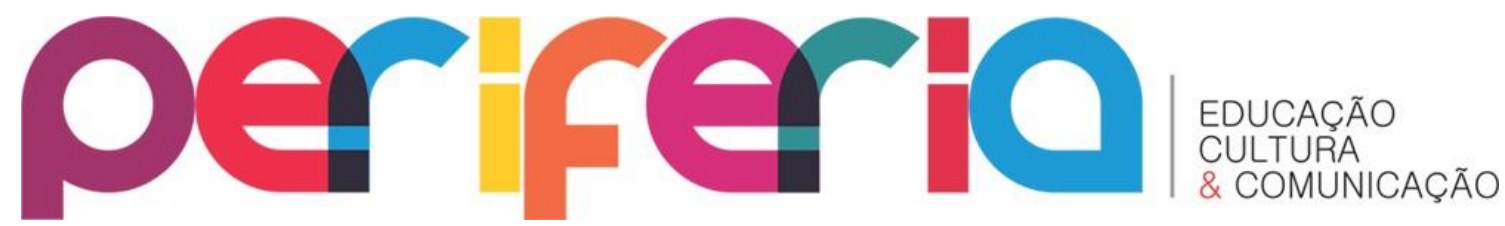

ISSN:1984-9540

DOI: $10.12957 /$ periferia.2020.54835

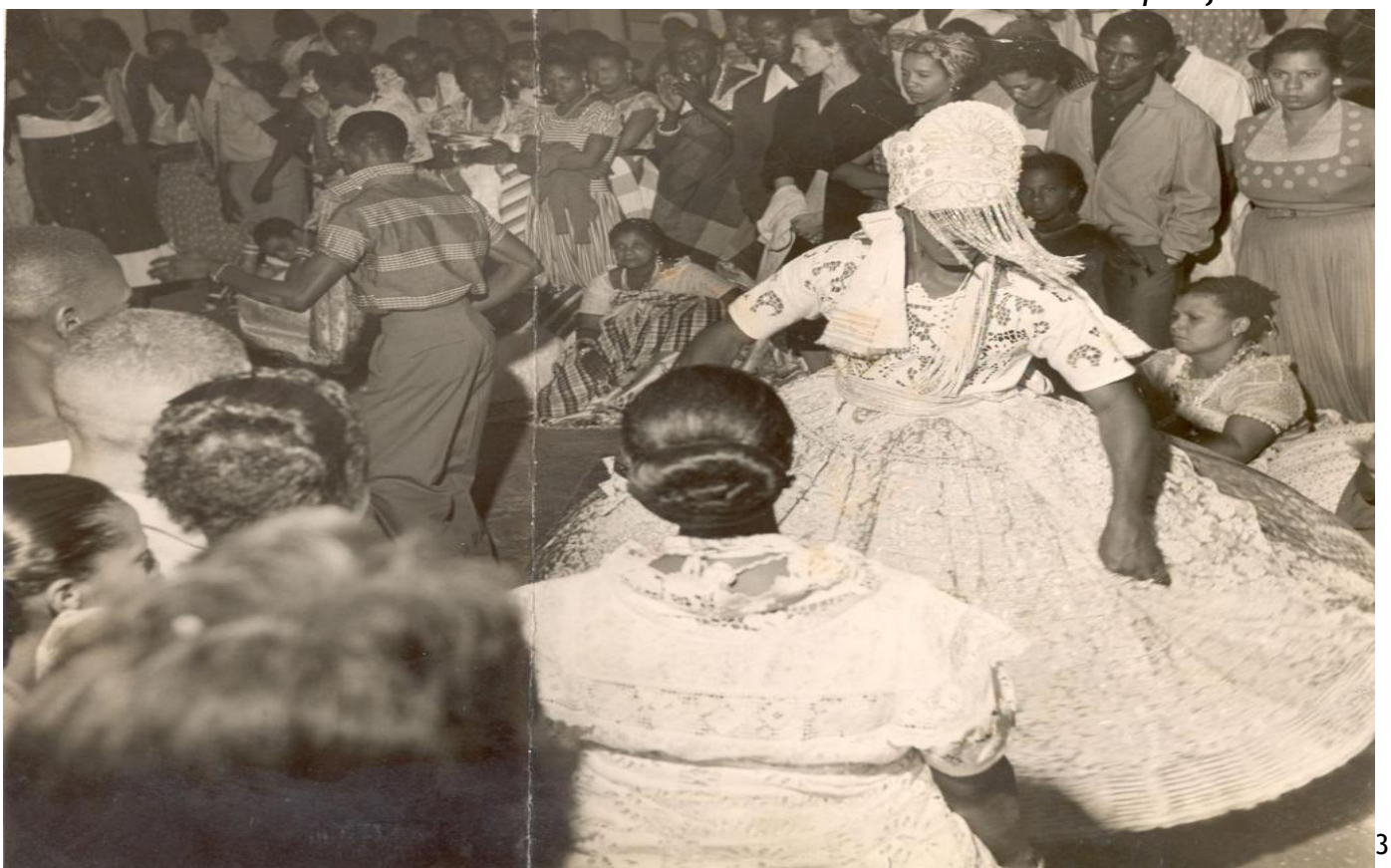

(...) Milhares de pessoas superlotavam o amplo barracão da Goméia de Caxias. Carros de luxo congestionavam a Rua General Rondon, na Copacabana caxiense. Muitos fogos. Bebidas em quantidade. Churrasco para quem quisesse já que dois bois gordos foram cortados para o candomblé. Gente de toda espécie estava lá dentro do barracão, assistindo à função. Gente de Copacabana, de Ipanema, do Leblon. Diplomatas, escritores, homens de negócios; velhos e crianças, crentes e descrentes. Católicos e protestantes. Uns levados pela curiosidade. Outros, pela vontade de verem de perto como a tradição yorubá é cultuada no Brasil. Entre as altas personalidades presentes; a nossa reportagem pôde anotar as seguintes: General Ciro de Rezende- chefe de polícia; General Pinto Aleixo - senador da República e senhora ${ }^{4}$.

João Alves Torres Filho, ou Joãozinho da Goméia ${ }^{5}$, foi um sacerdote baiano do candomblé Angola que ficou muito conhecido como "Rei do Candomblé" entre

\footnotetext{
${ }^{3}$ Foto do Correio da Manhã de 21 de dezembro de 1953

${ }^{4}$ Diário da noite, 18 de agosto de 1952.

${ }^{5}$ Segundo Raul Lody e Vagner Gonçalves da Silva, em Joãozinho da Goméia: o lúdico e o sagrado na exaltação ao candomblé, Joãozinho da Goméia foi um personagem polêmico na história recente das religiões afro-brasileiras, tendo uma atuação determinante na ampliação das fronteiras entre os ritos de candomblés e a sociedade brasileira. Joãozinho derrubou de certa forma os limites que impediam o acesso à liturgia e à ritualística dos terreiros, que até então eram conhecidos apenas por quem fazia parte das famílias de santo, derrubando rótulos, estigmas pejorativos e preconceitos.
}

Periferia, v. 12, n. 3, p. 67-93, set./dez. 2020 


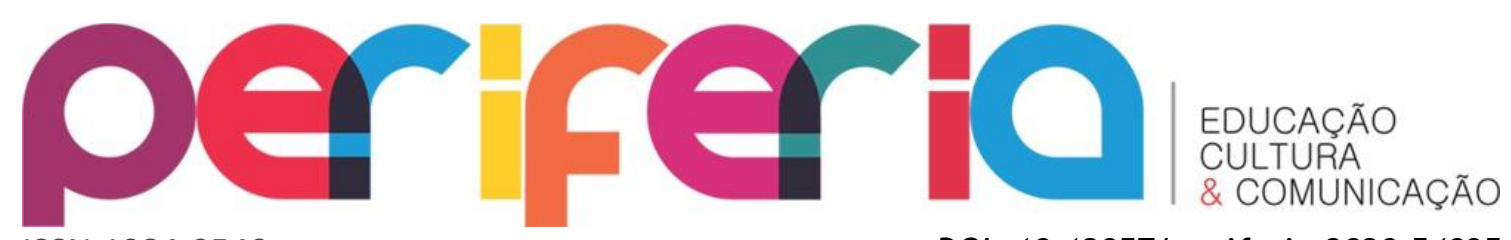

ISSN:1984-9540

DOI: $10.12957 /$ periferia. 2020.54835

os períodos de 1940 e 1971 , tendo sua iniciação ${ }^{6}$ relacionada ao terreiro dirigido pelo pai de santo Severiano Manoel de Abreu, o Jubiabá. O local era popularmente conhecido como "Centro Espírita Luz e Caridade" 7 que tinha como patrono São Tomé, mas que era um terreiro de candomblé caboclo/angola, localizado no Morro da Cruz do Cosme em Salvador.

Segundo o antropólogo Júlio Braga (1995), Jubiabá foi um personagem da obra de Jorge Amado publicada em 1935, mas também foi um dos "mais famosos pais-de-santo da Bahia na primeira metade do século XX", que se projetou como líder religioso protegido por um caboclo que the deu fama nas páginas dos jornais, tornando-o respeitado. Severiano ${ }^{8}$ tinha status na Bahia de grande chefe político que comandava uma legião de eleitores, o que the conferia prestígio e poder entre a população pobre e as grandes fortunas locais. A sua representatividade de liderança religiosa influenciava nas boas relações com a elite local, tendo em pouco tempo de atuação como pai de santo multiplicado inexplicavelmente a sua fortuna, lhe rendendo o interesse tanto da imprensa quanto dos intelectuais.

E foi pelas mãos do caboclo de Severiano que nasceu o caboclo Pedra Preta, o primeiro guia espiritual de Joãozinho da Goméia, que foi iniciado no candomblé de caboclo9 no dia 21 de dezembro de 1930.

A relação de Joãozinho com Severiano não foi ainda explorada pela escrita acadêmica, e pode, certamente, explicar muito das estratégias criadas pelo sacerdote da Goméia ao longo de sua trajetória dentro e fora do sagrado, afinal Severiano conviveu intimamente com Joãozinho a ponto de ser escolhido como

\footnotetext{
${ }^{6}$ Joãozinho informa em depoimento (para tese de doutorado) da então antropóloga Giselle CossardBinon que o terreiro de Jubiabá era Caboclo com um pouco de Angola, que não fazia muito de Angola e nem se preocupava com isso.

${ }^{7} \mathrm{Na}$ minha pesquisa de mestrado constatei que muitos terreiros baianos usavam o nome social de Centros Espíritas, escolhendo como patronos espirituais santos católicos e não orixás africanos para evitar as batidas policiais, já que o espiritismo kardecista não era reprimido como as religiões de matrizes africanas.

${ }^{8}$ Severiano era fazendeiro, proprietário de uma enorme extensão de terras que cruzava fronteiras com outros Estados, desconstruindo o estigma do pai de santo pobre e ignorante tão reforçado pela imprensa da primeira metade do século XX.
}

9 Segundo Olga Gudolle Cacciatore candomblé de caboclo é um misto de rituais bantos, europeus (espíritas e católico-populares) e indigenas. A diferença principal é que os orixás não descem diretamente entre os homens, mas são representados por entidades caboclas. Os caboclos bebem, fumam e dão consultas aconselhando e receitando cura para os males dos crentes.

Periferia, v. 12, n. 3, p. 67-93, set./dez. 2020 


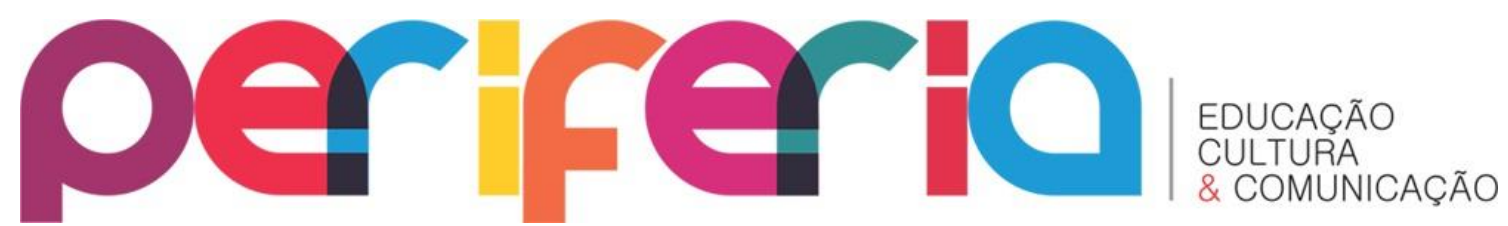

ISSN:1984-9540

DOI: $10.12957 /$ periferia. 2020.54835

aquele que comandaria o Axé do Centro Espírita de Severiano após a sua morte, o que acabou não acontecendo por conta dos ciúmes que a relação de amizade entre Severiano e Joãozinho despertava nos filhos de santo da casa.

Esta animosidade afastou Joãozinho em definitivo, sendo uma das responsáveis pelo nascimento do seu primeiro terreiro no bairro da Ladeira da Pedra em Salvador - um lugar muito simples herdado da sua madrinha ${ }^{10}$ para que o caboclo Pedra Preta pudesse fazer suas consultas, e pelo local ser muito pequeno não comportava a quantidade de consulentes que buscavam cura espiritual pela entidade; o que de fato causou a transferência para um lugar maior localizado na rua direita da Goméia ${ }^{11}$ que, segundo Jorge Amado $^{12}$, situava-se no quilômetro 3 da estrada de rodagem do bairro de São Caetano, em Salvador.

Muitos foram os que questionaram a iniciação de Joãozinho dentro de um terreiro de caboclo, considerando que neste tipo de candomblé não existia feitura no santo como acontecia nos candomblés tradicionais da nação ketu. Joãozinho convivera com o questionamento acerca do fato de não ter sido recolhido, e não ter aprendido as coisas do candomblé do modo tradicional.

\footnotetext{
10 Joãozinho assumiu o terreiro após a morte da sua madrinha.

${ }^{11}$ Quando Joãozinho iniciou a sua vida religiosa em 1930 aos 15 anos de idade passou a ser conhecido como João da Pedra Preta, um título que o acompanhou mesmo quando seu terreiro passou a funcionar na rua direita da Gomeia (1936), onde ficou conhecido como Joãozinho da Goméia. Mas a questão era que o nome João da Pedra Preta simbolizava o poder e a força do caboclo que atuava na área de cura de doenças e de abertura de caminhos materiais e espirituais. Foi graças a esta atuação que Joãozinho saiu do bairro da Ladeira das Pedras, onde atendia majoritariamente pessoas muito pobres. Este primeiro terreiro era candomblé de caboclo, e Joãozinho passa a ser Angola quando se transfere para a Goméia. Jorge Amado diz que a Goméia de São Caetano é ora nagô, ora angola e é apenas candomblé de caboclo nas festas do Seu Pedra Preta. O Olwô Agenor Miranda Rocha me informou em entrevista cedida em 2001 para a monografia de Graduação De São Caetano à Caxias que Seu Pedra Preta era um caboclo de Obaluaê, e não de Ogum como informara Edson Carneiro em Religiões Negras: notas de etnografia religiosa, acrescentando que na época em que o livro foi escrito associavam-se naturalmente muitos caboclos a Oxossi e a Ogum, e os que carregavam no nome o elemento "pedra" podiam ser identificados como caboclos de Xangô. $O$ que pode facilmente ser comprovado pelo material de imprensa consultado para a pesquisa da minha pesquisa de mestrado que está ainda em fase de escrita: nas festas de Obaluaê e de iniciação de iaôs da Goméia de São Caetano (1946-1949) e as da Goméia de Duque de Caxias (1951-1971) dançavam lado a lado o caboclo Pedra Preta e Obaluaê. O fotógrafo Pierre Verger em 1948, quando visita a Goméia de São Caetano fotografa estas presenças, reforçando a relação entre caboclo e orixá, e abrindo lacunas para questionamentos futuros.

${ }^{12}$ AMADO, Jorge. Terreiro de Joãozinho da Goméia, pp. 155. In: Bahia de todos os santos: guia de ruas e mistérios.
}

Periferia, v. 12, n. 3, p. 67-93, set./dez. 2020 


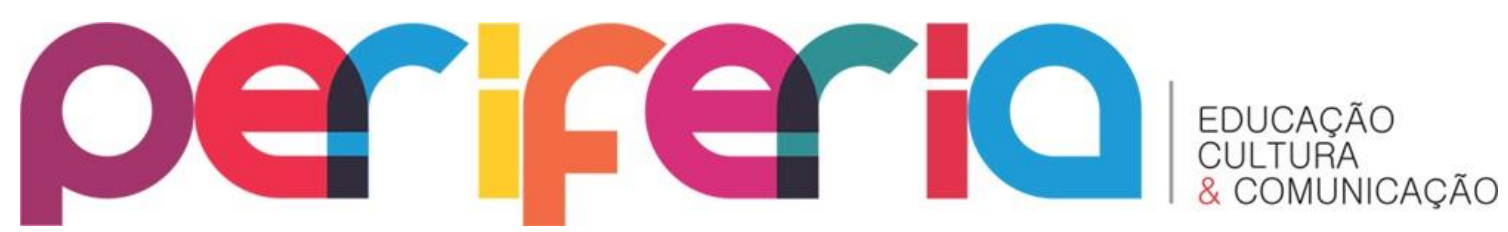

ISSN:1984-9540

DOI: $10.12957 /$ periferia. 2020.54835

Muitas lideranças ${ }^{13}$ religiosas da época afirmavam categoricamente que ele tinha visitado muitos terreiros de nações distintas, e aprendido um pouco com cada Nação, e esta era a essência do seu candomblé. Inclusive este foi o principal ${ }^{14}$ incômodo que a presença de Joãozinho despertara no seio do panteão do candomblé tradicional baiano. 0 jornal Diário da Noite de $1936^{15}$ afirma que entre 11 de junho a 21 de dezembro de 1930, ele havia sido recolhido à camarinha para a realização da sua feitura, aprendendo ali os fundamentos de todos os orixás, principalmente os de Exu, lansã, Oxossi e dos Caboclos. Essa informação sobre o recolhimento é fundamental para compreender o conhecimento amplo que ele tinha sobre as coisas do candomblé caboclo, já que essa era a natureza do terreiro de Jubiabá.

Em 1936, Joãozinho foi convidado pelo jornalista e folclorista Edson Carneiro para fazer parte dos preparativos do II Congresso Afro-brasileiro que seria organizado em Salvador para divulgação de estudos da cultura negra baiana e do folclore ${ }^{16}$. 0 evento tinha também um intuito maior, que era o de pressionar as autoridades pela liberdade do culto afro-religioso, e Joãozinho da Goméia foi escolhido como uma espécie de porta voz do candomblé caboclo baiano, atuando como um "intelectual mediador". O status conseguido por Joãozinho era até então relacionado ao respeitado Martiniano Eliseu do Bonfim - porta voz do terreiro da Casa Branca, ministro de Xangô e informante de Nina Rodrigues.

A presença de intelectuais junto a Joãozinho foi identificada em 1936, quando a Goméia passa a ser visitada por Aydano Couto Ferraz e Edson Carneiro que leva a equipe ${ }^{17}$ de reportagem do jornal Diário da Noite e do Correio

\footnotetext{
${ }^{13}$ Martiniano Eliseu do Bonfim e Menininha do Gantois questionavam a legitimidade de Joãozinho da Goméia à frente de um candomblé.

${ }^{14}$ A problemática da idade de Joãozinho foi outro fator que reprovava sua autoridade como pai de santo. Assumiu um terreiro aos 15 anos de idade, e já construía um nome de peso em Salvador.

${ }^{15}$ Diário da Noite (RJ) de 27 de agosto de 1936.

16 Uso a definição folclore negro por conta do livro: O Folclore negro do Brasil: demopsicologia e psicanálise de Arthur Ramos que teve em 1935 sua primeira publicação editada pela Civilização Brasileira.

$17 \mathrm{Em} \mathrm{1937,} \mathrm{Joãozinho} \mathrm{surge} \mathrm{no} \mathrm{Diário} \mathrm{da} \mathrm{Noite} \mathrm{de} 9$ de setembro de 1936 como uma liderança religiosa que desejava liberdade de culto para os terreiros baianos, sendo esta a primeira projeção do pai de santo feita pelo jornalista e folclorista Edson Carneiro, que usa a imprensa baiana para divulgar seu II Congresso Afro-brasileiro ${ }^{17}$. Conhecedor do brilho de comunicação de Joãozinho, Edson Carneiro usou o pai de santo como "garoto-propaganda" do seu Congresso, já que,
}

Periferia, v. 12, n. 3, p. 67-93, set./dez. 2020 


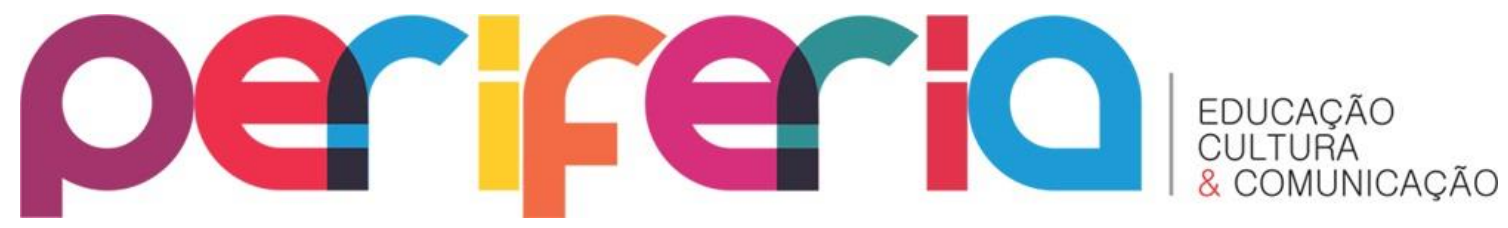

ISSN:1984-9540

DOI: $10.12957 /$ periferia. 2020.54835

Paulistano até o terreiro para que Joãozinho falasse da sua participação no evento.

Com isso a Goméia abre as suas portas para outros intelectuais, que encontram naquele lugar uma importante referência para os estudos do folclore negro e do candomblé de caboclo. A identificação com o caboclo Pedra Preta foi responsável pelo inicio da trajetória de Joãozinho, que de 1930 a 1940 ficou conhecido como João da Pedra Preta, sendo noticiado desta forma na imprensa, e entre a intelectualidade que frequentava o terreiro da Rua Direita da Goméia no bairro de São Caetano, em Salvador ${ }^{18}$.

\section{A Goméia baiana(1936-1949) ${ }^{19}$}

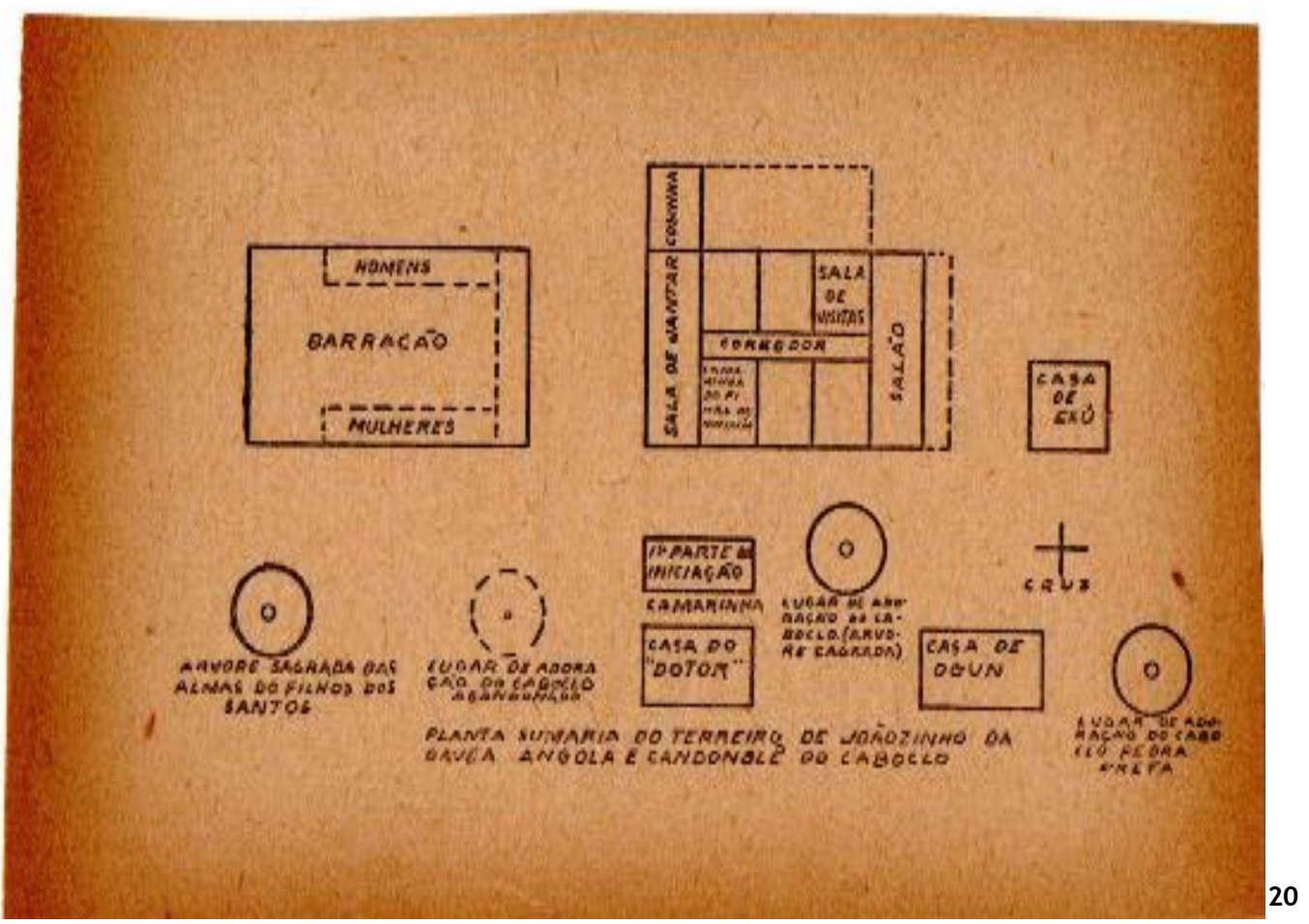

interessado no estudo dos candomblés de caboclo, se aproximou de Joãozinho e o divulgou nos seus livros Religiões Negras e Negros bantos.

18 Joãozinho se mudou para o terreiro da rua Direita da Goméia em 1936.

19 O corte temporal é relativo ao período de ocupação em 1936 e o período da saída de Joãozinho para construir uma nova sede na rua General Rondon, em Duque de Caxias. O terreiro baiano continuou existindo sob o comando de Edith Apolinária de Santana, mais conhecida como Samba Diamongo, que foi filha de santo do terreiro Bate-Folha.

${ }^{20}$ Planta sumária do terreiro de São Caetano que Roger Bastide constrói para Imagens do Nordeste místico em branco e preto. Bastide em 1945 identifica o terreiro como de candomblé Angola e Caboclo. Chamo atenção para a importância dos caboclos no terreiro com lugares de adoração para o caboclo abandonado, árvores dedicadas a adoração da entidade, lugar específico para adorar o caboclo pedra preta. Também destaco um espaço interno para a sala de jantar, perto da cozinha, da sala de visitas, e do salão de festas, o que confirma a importância de se ter um espaço de

Periferia, v. 12, n. 3, p. 67-93, set./dez. 2020 


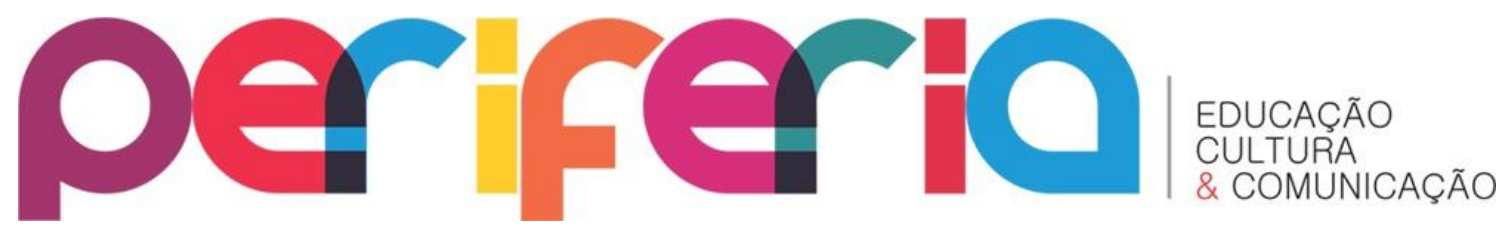

ISSN:1984-9540

DOI: $10.12957 /$ periferia.2020.54835

No livro Imagens do Nordeste místico em branco e preto, o sociólogo Roger

Bastide traz uma lista de terreiros soteropolitanos com dados fornecidos pela polícia baiana ${ }^{21}$. Dentre estes 86 terreiros, identificou 25 caboclo/angola funcionando entre bairros de São Caetano e Liberdade. 0 terreiro da Goméia é localizado, dentre outros funcionando bem perto, na mesma rua Direita, e utilizando o mesmo nome. 0 que não se pode constatar é se foi uma conclusão própria de Bastide, ou se de fato existiram estes terreiros com o nome Goméia22.

\section{Quadro 1- Os 25 Terreiros caboclo/angola identificados e catalogados por Roger Bastide entre 1942 e 1945.}

\begin{tabular}{|l|l|l|}
\hline Dirigente & Local/ Nação & Nome do terreiro \\
\hline Manoel Natividade & Brotas/Angola & Casa do caboclo Neve Branca \\
\hline Mariazinha & $\begin{array}{l}\text { Alto do nordeste/ Nagô e } \\
\text { Angola }\end{array}$ & Casa de Oxum \\
\hline Manoel Menezes & $\begin{array}{l}\text { Entrada do } 1^{\circ} \text { quilometro da } \\
\text { via de rodagem para } \\
\text { Goméa/Angola }\end{array}$ & Casa de Omulu \\
\hline Hilário & $\begin{array}{l}\text { Rio vermelho de cima/ Nagô } \\
\text { e Angola }\end{array}$ & Casa Viva Deus \\
\hline Oswaldo & Vivi da Barra/Angola & Casa de Ogum \\
\hline Manoel Luzio & Rio vermelho de cima & Casa cabocla \\
\hline
\end{tabular}

convivência e de refeições para visitantes, ou seja, para pessoas que não pertenciam ao candomblé. Nas festas de terreiro estes espaços são fundamentais para as articulações do pai de santo.

${ }^{21}$ BASTIDE, Roger. Imagens do nordeste místico em branco e preto. Seção de livros da Empresa gráfica "O Cruzeiro" S.A. Rio de Janeiro, 1945. A pesquisa foi realizada entre os anos de 1942 e 1945.

${ }^{22}$ Este fato seria facilmente constatado com o cruzamento desta informação com relatos orais, o que foi impossível de ser obtido pelo fato de não ter conseguido acessar as memórias atuais de pessoas da família Goméia. Os relatos que consegui foram em 2001 com lleci da Oxum, a mãe criadeira da Goméia; Sinah Vuru; Mãe Omindarewa - a francesa da filha de santo de Joãozinho, e o Olwô/Olossaim Agenor Miranda Rocha. Com exceção de Tata Anselmo, do terreiro Mokambo de Salvador, outros membros da família Goméia nunca me deram entrevistas para a pesquisa que desenvolvi de 2001 a 2003 para a monografia de graduação em da Universidade do Estado do Rio de Janeiro, nem para a pesquisa do mestrado em historia da Universidade Federal Fluminense. Abro uma ressalva também para Mãe Seci Caxi, que sempre se pôs à minha disposição para entrevistá-la, mas pelo agitado ano de 2019 que foi todo ocupado pelo Desfile da escola Grande Rio, que levou para Avenida um enredo sobre Joãozinho da Goméia, e pelo processo de Tombamento do INEPAC. Ambos os eventos adentraram 2020, com a nefasta presença da quarentena pandêmica do Covid-19, que impossibilitou que Seci Caxi pudesse me contemplar com suas memórias.

Periferia, v. 12, n. 3, p. 67-93, set./dez. 2020 


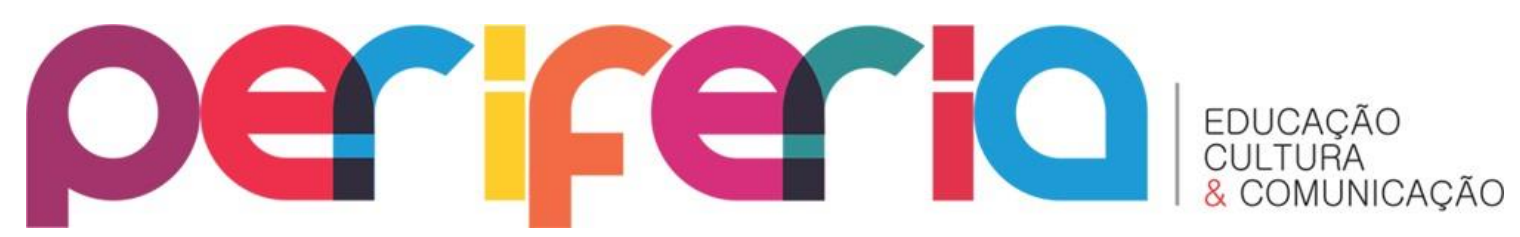

ISSN:1984-9540

DOI: $10.12957 /$ periferia.2020.54835

\begin{tabular}{|c|c|c|}
\hline D. Risoleta & Brotas/ Caboclo & Casa de Oxalá e Ogum \\
\hline D. Cirila & $\begin{array}{l}\text { Avenida Câmara (via } \\
\text { Calabar)/ caboclo }\end{array}$ & Casa de Caboclo \\
\hline D. Constancia dos Santos & $\begin{array}{l}\text { Alto do Gato (via Federação)/ } \\
\text { Caboclo }\end{array}$ & Casa de caboclo \\
\hline Sem nome de dirigente & $\begin{array}{l}\text { Alto dos pombos (ponte da } \\
\text { Federação junto ao Campo } \\
\text { santo) }\end{array}$ & Casa de caboclo \\
\hline Sr. Arthur & Amaralina & Casa de caboclo \\
\hline Sem nome de dirigente & $\begin{array}{l}\text { Pedra da Sereia (via Av. } \\
\text { Presidente Vargas) }\end{array}$ & Caboclo/angola \\
\hline Andrea Torquatto & $\begin{array}{l}\text { Rio vermelho de baixo/ } \\
\text { Angola }\end{array}$ & Bougun \\
\hline Sem nome de dirigente & $\begin{array}{l}\text { Ladeira perto do Engenho } \\
\text { velho }\end{array}$ & Casa de João de Deus \\
\hline Vavá Luiza de Bruno & $\begin{array}{l}\text { Engenho velho de brotas/ } \\
\text { caboclo e queto }\end{array}$ & Casa de Oxalá \\
\hline Sr. Americo & $\begin{array}{l}\text { Ladeira da Vila America / } \\
\text { caboclo }\end{array}$ & Casa de Xangô \\
\hline D. Persília & Engenho velho/ caboclo & Casa de Oyá \\
\hline Sem nome de dirigente & $\begin{array}{l}\text { Monte de Belém (Vila } \\
\text { América)/ Angola e Caboclo }\end{array}$ & Sem nome de terreiro \\
\hline Sr. Amorim & $\begin{array}{l}\text { Estrada da Liberdade/ } \\
\text { Caboclo }\end{array}$ & Casa do Sr. Amorim \\
\hline Pedro Evaristo dos Santos & Rua direita da Goméa n 151 & $\begin{array}{l}\text { * Goméa (outro terreiro } \\
\text { identificado como Goméia) }\end{array}$ \\
\hline Zé pequeno & $\begin{array}{l}\text { Capelinha de São Caetano/ } \\
\text { Angola/ Igexa }\end{array}$ & Casa de Zé pequeno \\
\hline Idalice Santos & São Caetano (Gomea)/ Igexa & Casa de Omulu e Xangô \\
\hline Pai Miguel de lemanjá & Liberdade/ Congo e Angola & Corta braço \\
\hline Mãe Sabina & Quintas de Brotas/ caboclo & Casa de Omulu \\
\hline Mãe Josefa Alves de Castro & Rua direita da Gomea & *Gomea de Santo Antônio \\
\hline
\end{tabular}

Em reportagem feita para $A$ Cigarra $^{23}$, Bastide define o candomblé da Goméia como "um apelo estético da união entre religião e arte". 0 dia que Bastide chegou ao terreiro era o da festa de "dar o nome", quando as filhas de santo se entregaram pra sempre aos Orixás. Bastide identificou que o sincretismo se

${ }^{23}$ A Cigarra foi uma revista mensal dirigida por Frederico de Chateaubriand, onde o fotógrafo Pierre Verger era um dos diretores de fotografia.

Periferia, v. 12, n. 3, p. 67-93, set./dez. 2020 


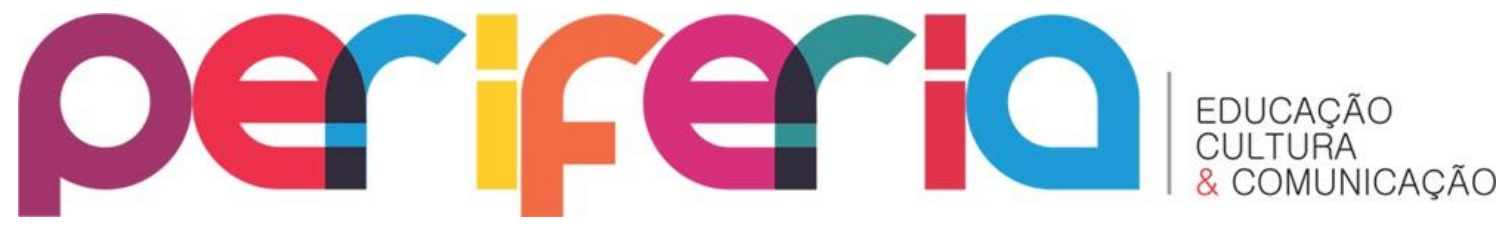

ISSN:1984-9540

DOI: $10.12957 /$ periferia.2020.54835

limitava a uma simples "justaposição" sobre o catolicismo, presente na decoração do terreiro que seguia "os padrões de beleza apreendidos das capelas barrocas". 0 sincretismo estava representado fortemente pelo altar dos santos católicos, que estava em um espaço separado do "pegi" africano enfeitado por pratos de frangos e de doces ofertados aos orixás simbolizados pelos "itas", as pedras sagradas que concentravam a força e a energia dos orixás e dos caboclos da Goméia.

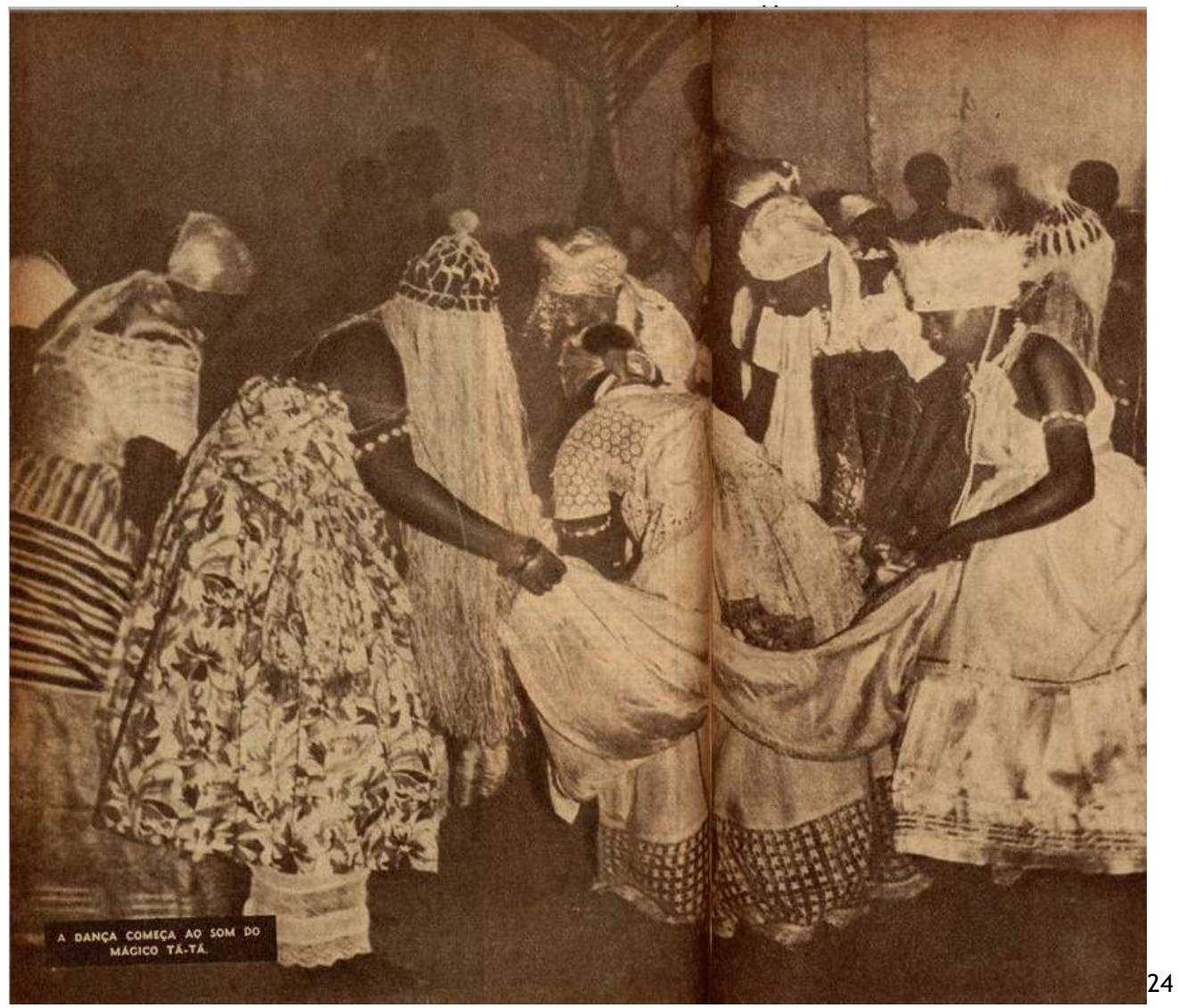

A Goméia de São Caetano recebeu o nome em quimbundo de Manso Bantuqueno Ngomenssa Kat'espero Gomeia, e começou a ser visitada entre 1943 e 1949 por intelectuais como Donald Pierson, Edson Carneiro, Jorge Amado, Lorenzo Turner, Pierre Verger e Roger Bastide. A mudança para Duque de Caxias aconteceu com a autorização de Oxossi e do Caboclo Pedra Preta após os festejos da Lavagem do Bonfim ${ }^{25}$ e do dia de lemanjá ${ }^{26}$. A presença desta intelectualidade colaborou

\footnotetext{
${ }^{24}$ Esta fotografia foi feita por Pierre Verger para a revista A Cigarra.

${ }^{25}$ É uma celebração inter-religiosa que acontece na quinta-feira que antecede o segundo domingo após o dia dos santos reis, no mês de janeiro.
}

Periferia, v. 12, n. 3, p. 67-93, set./dez. 2020 


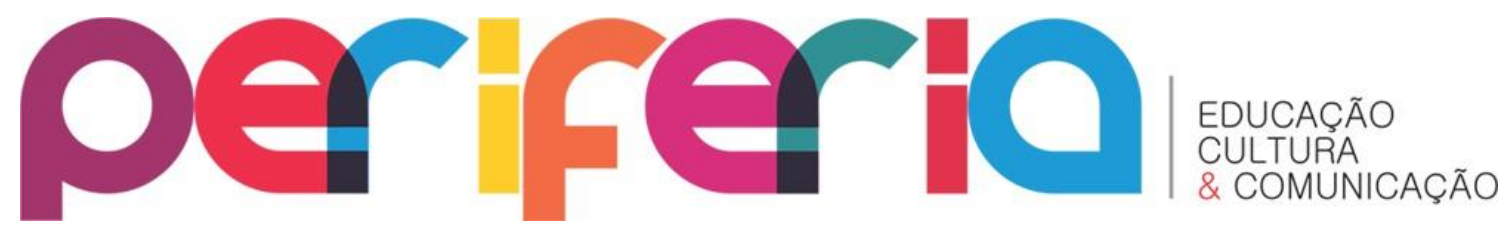

ISSN:1984-9540

DOI: $10.12957 /$ periferia. 2020.54835

com a entronização de Joãozinho à condição de Realeza do candomblé, e transformou a Goméia em uma fonte de estudos do folclore brasileiro. ${ }^{27}$ Não se pode ignorar a passagem de Joãozinho por Salvador, já que foi um período fundamental para entender: Que rei era esse? Todas as respostas para esta pergunta estão nas ladeiras do bairro da Liberdade, onde Joãozinho transitava entre os festejos da cultura popular e as festas do catolicismo baiano. Estão nas apresentações no Teatro Jandaia e na Rádio Metropolitana Fm, onde ele se apresentou bastante após a realização do congresso afro-brasileiro de 1937. Para entender a matéria que constituía Joãozinho da Goméia é preciso revisitar os arquivos públicos baianos onde estão informações sobre este João da Pedra Preta que será aclamado nos jornais da imprensa carioca como o tão conhecido Rei do Candomblé.

${ }^{26}$ Em dezembro de 1948, Joãozinho se despede de Salvador no Teatro Jandaia com uma apresentação do seu Balé folclórico Oxumaré, e como ele participava dos festejos religiosos como a lavagem do Bonfim, por dedução, acreditamos que a data mais próxima da sua saída de Salvador tenha acontecido após a festa de lemanjá, da qual ele participava todos os anos, de acordo com o que versa o material de imprensa consultado nos arquivos do Centro Nacional de Folclore e Cultura Popular do Rio de Janeiro. A festa de lemanjá ocorre no dia 2 de fevereiro.

${ }^{27}$ Foi a partir do terreiro da Goméia que antropólogos começaram a pensar no candomblé como um objeto de investigação em nível stricto sensu. O Olwô Agenor Miranda Rocha me relatou em 2001 que mesmo que os estudiosos se interessassem pelos terreiros nagôs, a pessoa de Joãozinho da Goméia atraía um interesse específico, porque os seus terreiros (tanto o de São Caetano quanto o de Duque de Caxias) eram milimetricamente distintos dos outros, a começar pelas festas, pela culinária, pela estética, pela ritualística: "Nunca pisei na Goméia, mas muita gente que vinha até minha pisava. Uns eram até filhos de santo da Goméia e vinha me visitar para aconselhamentos. As festas daquele lugar eram de fato atraentes, e o Joãozinho sabia usá-las para conseguir o que queria. Muito filho de santo dele precisava de emprego ou até comprar uma casa, e nas festas ele conseguia com um político, um artista, era um verdadeiro império".

Periferia, v. 12, n. 3, p. 67-93, set./dez. 2020 


\section{per
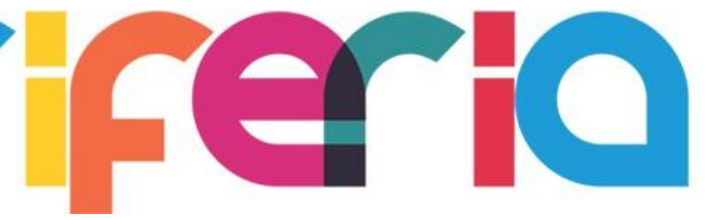 \\ EDUCAÇÃO \\ CULTURA}

ISSN:1984-9540

\section{TERREIRO DE CANDOMBLE' - FONTE DE' ESTUDOS DO FOLK-LORE BRASILEIRO}

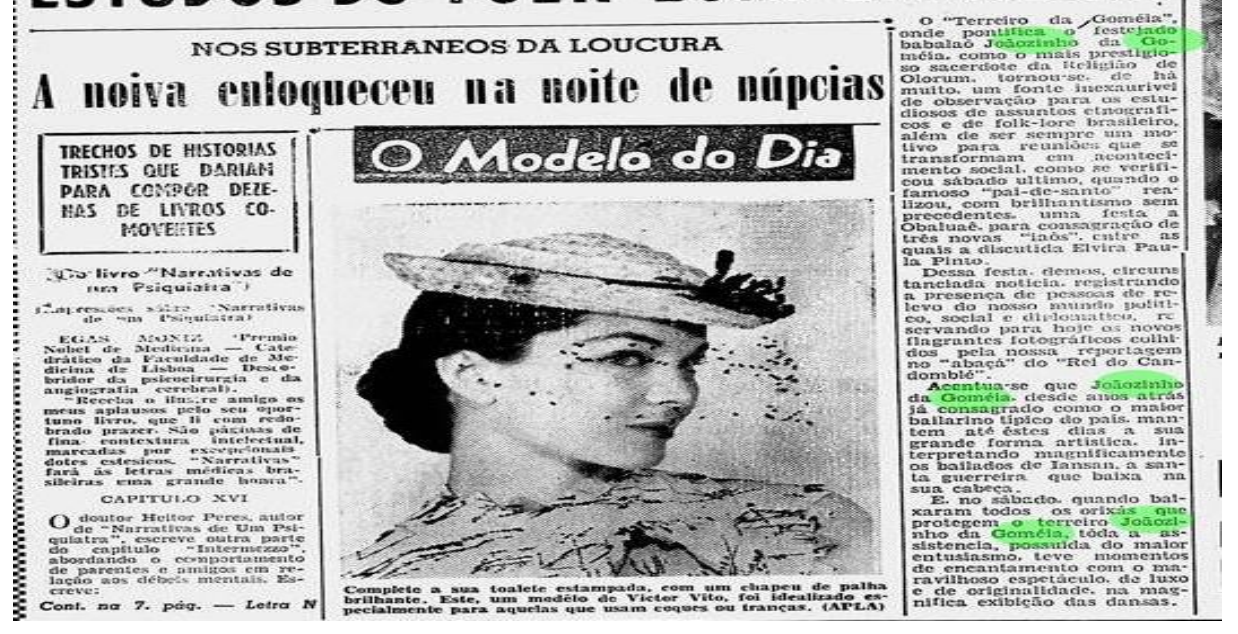

Para entender as estratégias de Joãozinho da Goméia através das festas de terreiro faz-se necessário conhecer o livro Guia de ruas e mistérios: Bahia de todos os santos do escritor baiano Jorge Amado, onde narra uma visita que fez à Goméia de São Caetano, descrevendo o terreiro como espetacular e demonstrando fascínio pelo lugar e pelo talento do bailado de Joãozinho. Ali, Jorge Amado descreveu a si mesmo como "ogã da Goméia"28, para enaltecer a importância de Joãozinho e lhe abrir alguns caminhos dentro e fora de Salvador, já que era conhecida a ligação estreita que Jorge Amado tinha com o terreiro do Gantois, tendo inclusive um cargo de ogã dado por Mãe Menininha.

O que é fundamental atentar é que o pai de santo usou elementos do sagrado para construir suas estratégias em busca de projeção. Negociou elementos do candomblé como a dança, a cura através da força dos Exus, caboclos e Orixás, da consulta nos búzios e da comida do terreiro. A Goméia era um projeto de vida para Joãozinho, e como tal podemos entender o terreiro de Duque de Caxias como uma extensão do terreiro de Salvador: os visitantes ricos e famosos da classe artística, do café soçaite, das forças armadas, da política, da polícia e as lideranças religiosas de tendas de umbanda (em Duque de Caxias) e do candomblé

${ }^{28} \mathrm{O}$ que fica perceptível é que as associações feitas por Jorge Amado, se identificando com a Goméia fazem parte das negociações por status, prestígio e poder traçadas por Joãozinho em toda a sua trajetória no candomblé.

Periferia, v. 12, n. 3, p. 67-93, set./dez. 2020 


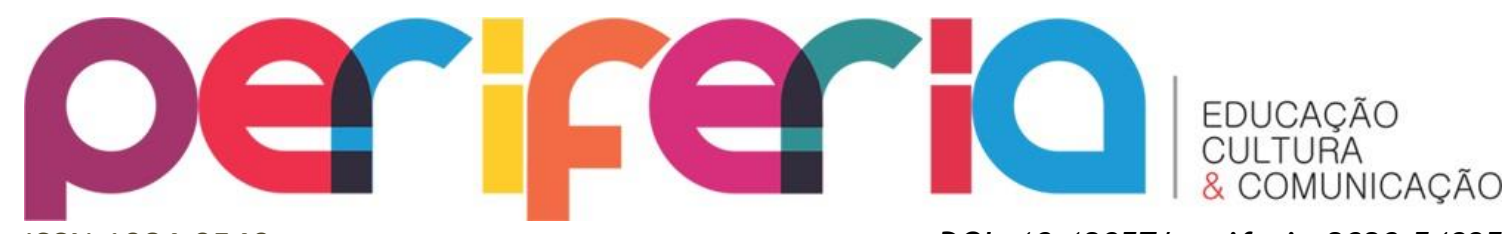

ISSN:1984-9540

DOI: $10.12957 /$ periferia. 2020.54835

eram os que podiam desfrutar das iguarias finas e raras servidas no terreiro da Goméia.

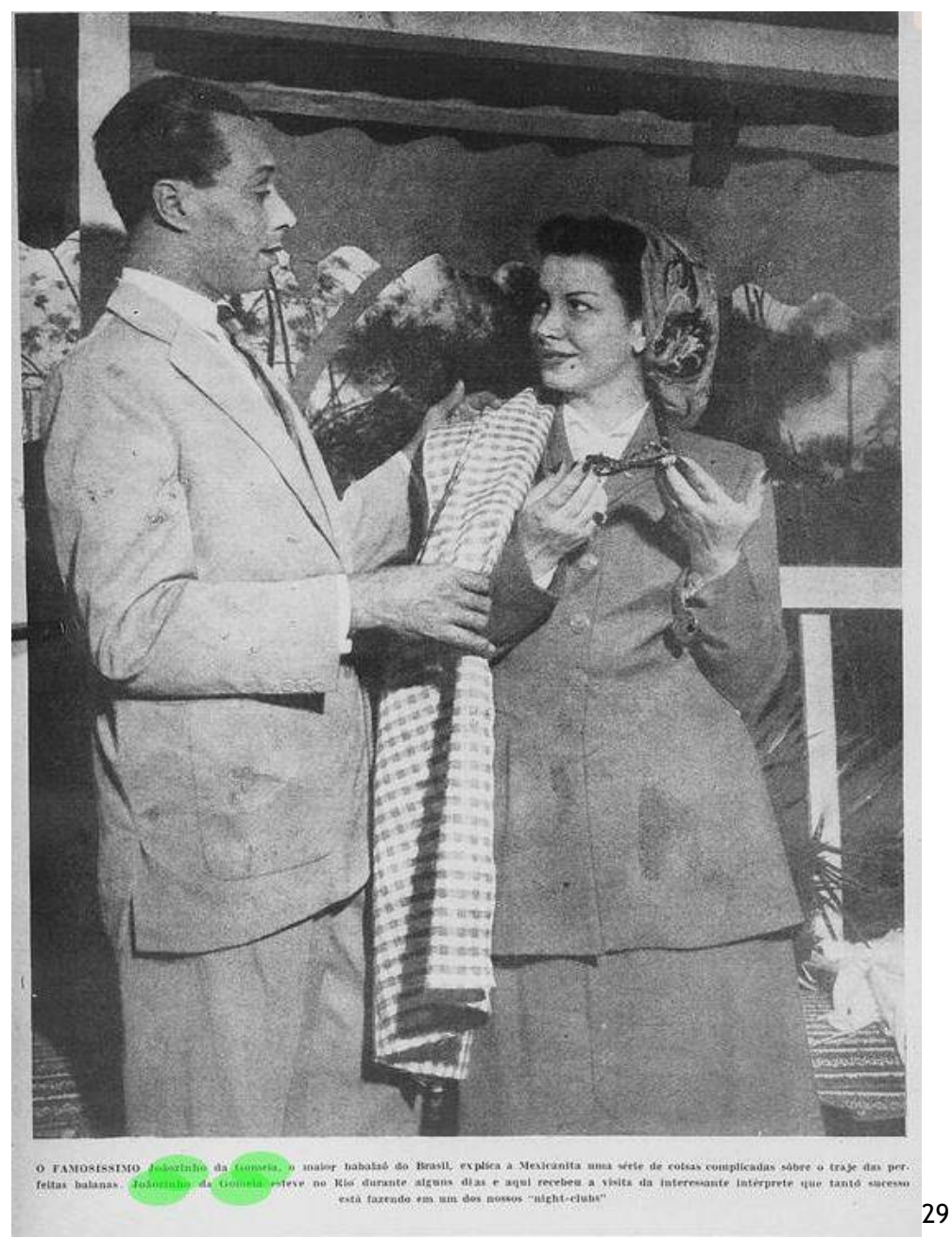

Joãozinho de fato usava o sagrado como moeda de troca como todas as lideranças do candomblé daqueles tempos. Em um cenário de perseguição e repressão aos candomblés, aquelas pessoas tinham de encontrar estratégias para sobrevivência das suas tradições, e Joãozinho, nos seis anos que esteve em contato direto com Severiano, aprendera como negociar sua própria sobrevivência em Salvador, e já no Rio de Janeiro barganhar favores com autoridades policiais e políticas.

${ }^{29}$ Revista A Cena muda de 5 de julho de 1949.

Periferia, v. 12, n. 3, p. 67-93, set./dez. 2020 


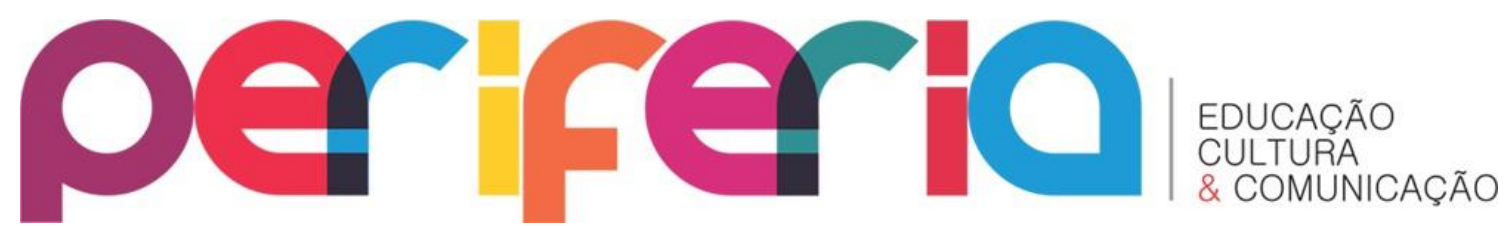

ISSN:1984-9540

DOI: $10.12957 /$ periferia. 2020.54835

O antropólogo Julio Braga (1995), ao falar sobre Severiano (Jubiabá), relata que muitos pais de santo na Bahia se valiam de relações de amizade para solicitar dos órgãos públicos e de políticos melhorias para o bairro ou algum favor especifico para amigos, parentes de sangue e de santo. Braga diz que estas lideranças ultrapassam os limites do sagrado.

A atriz Mexicanita, ${ }^{30}$ por exemplo, foi conhecer a Goméia de Duque de Caxias em 1949, porque Joãozinho já era uma referencia dentro das religiões afrobrasileiras (umbanda ${ }^{31}$ e candomblé), e também porque já era conhecido como um famoso bailarino dos Orixás.

No inicio dos anos 1940 já era dono da Companhia baiana de folclore Oxumaré, muito conhecida por artistas de renome do cenário teatral e musical do balé afro como Abdias do Nascimento, Any Guayba, Eros Volusia, Haroldo Costa, Mercedes Baptista, Ruth de Souza e Solano Trindade.

Uma das ultimas reportagens realizadas na Gomeia de São Caetano foram as feitas pelo fotografo e cinegrafista Isaac Rozemberg e pelo jornalista Mario Augusto da Rocha para o jornal A Manhã ${ }^{32}$ de 13 de fevereiro de 1949. A reportagem informa que I. Rozemberg ${ }^{33}$ esteve na Goméia de São Caetano para filmar as festas do terreiro, e toda a ritualística envolvida.

\footnotetext{
${ }^{30}$ A reportagem fotográfica do jornalista Arnaldo Vieira da revista $A$ Cena muda de 5 de julho de 1949, trouxe a relação de amizade de Joãozinho com a intérprete Mexicanita. O repórter cita Joãozinho como o maior babalaô do Brasil e que impressionara a Mexicanita e seus amigos com imagens, peças e trajes usados por filhas de santo assim como adornos.

31 Parte da imprensa carioca identificava Joãozinho com o cenário umbandista e não com o do candomblé. Muitos o intitulavam de Rei da Umbanda, ou pai de santo umbandista, o que claramente estava vinculado à ligação de Joãozinho com os caboclos e com a presença de um peji com imagens de santos católicos, o que era característico do culto umbandista. Joãozinho também era muito amigo de lideranças umbandistas como Orlando Pimentel, médium do caboclo cobra coral, e Tancredo da Silva Pinto, do Omolocô, além de sempre estar ligado às festividades e festivais de tendas umbandistas de outros lugares como Santos (SP), Vitória (ES), Rio Grande do Sul e Distrito Federal. A ligação com a Umbanda o transformou em um pai de santo itinerante a partir dos anos de 1960, período em que o campo umbandista já havia se solidificado principalmente no Estado do Rio de Janeiro.

32 Reportagem Os orixás descem sobre o terreiro. A Manhã, 13/02/1949

${ }^{33}$ Infelizmente, não tive acesso a informações sobre as filmagens feitas por Isaac Rozemberg na Goméia e que são um importante documento sobre o terreiro e seu pai de santo.
}

Periferia, v. 12, n. 3, p. 67-93, set./dez. 2020 


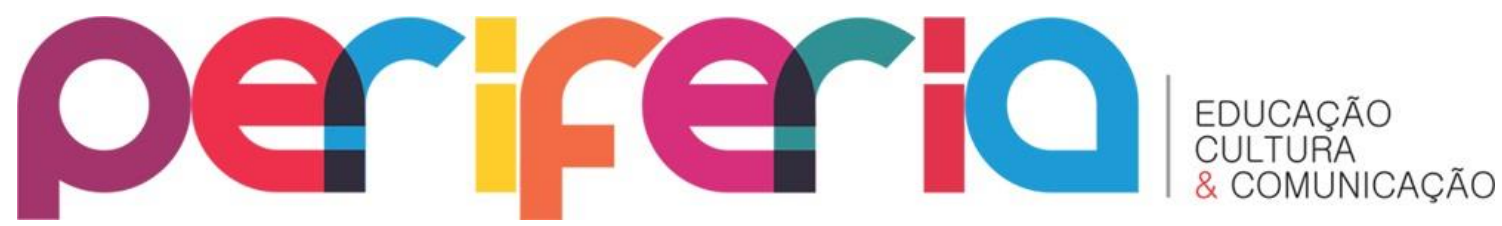

ISSN:1984-9540

DOI: $10.12957 /$ periferia.2020.54835

A Goméia festiva de Caxias: Aqui nasceu o Império do candomblé

(...) Joãozinho da Goméia, chega aos 35 anos de idade, no ano de 1949, ao município de Duque de Caxias, na Rua General Rondon, bairro Copacabana acompanhado de sua mãe de sanguea Vó Senhora e algumas de suas filhas de santo. Começa a investigar a viabilidade de instalar uma Roça de candomblé naquele lugar. Ele estava desacreditado com a sua atuação como pai de santo em Salvador, pois sabia que lá o campo religioso era tomado pela nação kêtu. Não que a roça da Goméia de lá tenha fracassado, nada disso é que aqui no Rio de Janeiro, o campo já estava naturalmente aberto para a umbanda, a macumba e os candomblés angola/caboclo. Aqui no Rio não tinha um nome de destaque já firmado, e Pai João encontrou a segurança de um território carente de um grande nome. Ele tinha consciência da sua importância e do seu brilho, mesmo estando decepcionado com Salvador. A instalação da Gomeia ampliou o espaço do culto afro-religioso, e também aumentou os recursos financeiros do entorno do terreiro, até luz elétrica e linha de ônibus o povo dali ganhou por causa de Pai João. Tudo melhorou!!!! ${ }^{4}$

De 1949 a 1971, as festas que aconteciam na Goméia eram as mais famosas da cidade do Rio de Janeiro, sendo divulgadas quase que diariamente nos jornais cariocas, com o intuito de atrair milhares de pessoas para superlotar o amplo barracão ${ }^{35}$. Carros de luxo congestionavam a Rua General Rondon, e muitos fogos iluminavam os céus de Duque de Caxias com a certeza de que naquele local estaria mais uma vez acontecendo uma festa de candomblé regada a muita bebida e a muita comida típica. É neste cenário que se localizam as organizações dos banquetes do Rei do Candomblé: a culinária de terreiro aqui desempenha algumas funções importantes, que não são apenas pertencentes ao âmbito do sagrado, ou seja, não seria apenas para agradar aos Caboclos, Exus, Inquices e Orixás do lugar, mas sim ao enorme contingente de pessoas interessadas nos ritmos afro-brasileiros e na cura para os males do corpo e do espírito.

As colunas erigidas no terreiro retratam bem a face arquitetônica do Império de Joãozinho, que acreditava estar desconstruindo o imaginário social sobre os candomblés, que eram citados pelos jornalistas dos anos 1920 a 1940 como abrigo

\footnotetext{
${ }^{34}$ Relato de Giselle Binon Cossard, mãe Omindarewa.

35 Termo designado para terreiro, Roça.
}

Periferia, v. 12, n. 3, p. 67-93, set./dez. 2020 


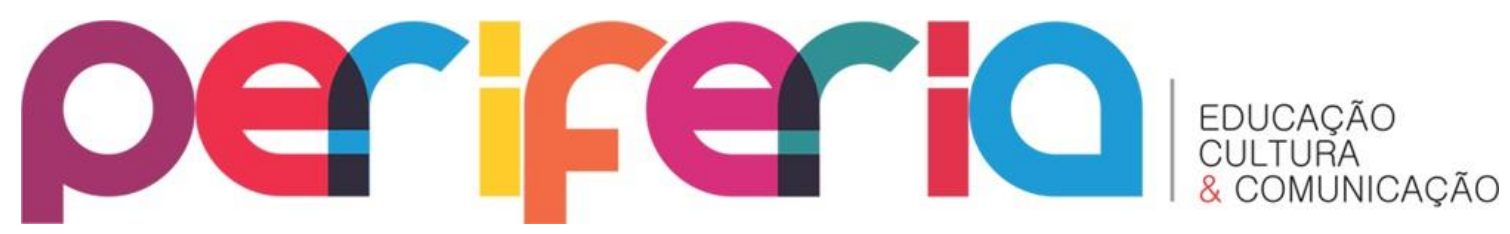

ISSN:1984-9540

DOI: $10.12957 /$ periferia.2020.54835

de satanismo e barbárie. As colunas remetiam à estética clássica. A coluna Grecoromana conferia um refinamento e transformava o terreiro em um lugar diferenciado.

0 arqueólogo Rodrigo Pereira mencionou que talvez Joãozinho quisesse "embranquecer" seu candomblé, o isolando de critérios racistas, e talvez estivesse aí a associação com a Umbanda, que na sua formação de 1920 a 1940 buscou se afastar de elementos negros - como os pretos velhos, exus e pombagiras. 0 próprio Joãozinho da Goméia não dava espaço nas suas sessões de gira para que essas entidades baixassem, segundo relato de lleci da Oxum - a mãe criadeira do terreiro:

(...) Pai João não gostava que baixasse pombagira no terreiro não!!!! Quando acontecia de baixar Exu e pombagira ele pegava pessoalmente a pessoa incorporada e saía com ela pra bem longe. Só voltava quando estava tudo resolvido. Em alguns casos a pessoa ficava recolhida ali mesmo pra fazer o santo, em outros casos ele botava a pessoa desincorporada no carro, e ela ia embora. Meu pai era autoritário!!!! Sabia controlar tudo. Nada fugia ao seu controle.

A amizade com jornalistas do Diário da Noite the garantira, em 4 de junho de 1949, um encontro na redação do Diário trabalhista com Abdias do Nascimento e Albert Camus, que o reconheceu "não apenas como o maior pai de santo da Bahia, mas como o maior bailarino típico do nosso país". ${ }^{36} 0$ terreiro exercia, desta forma, um papel político, e não se pode negar que, ao circular entre senadores, embaixadores estrangeiros e presidentes da República, o pai de santo não tenha se espelhado nos banquetes presidenciais que aconteciam no palácio do Catete para desenhar suas estratégias de poder. ${ }^{37}$

Nascimento (2003) cita que a fama da Goméia de Caxias fez a empresa de ônibus União criar a linha "Caxias-Copacabana" e no para-brisa fixou Via Joãozinho

\footnotetext{
${ }^{36}$ Diário da Noite (RJ), ano 1949. Edição 04563(1)

37 De fato, ele sabia o que acontecia nos grandes banquetes do Catete e procurava reproduzir dentro do terreiro. Em 1952, foi chamado para dançar para Dean Achesson, ex-secretário de Estado dos Estados Unidos.
}

Periferia, v. 12, n. 3, p. 67-93, set./dez. 2020 


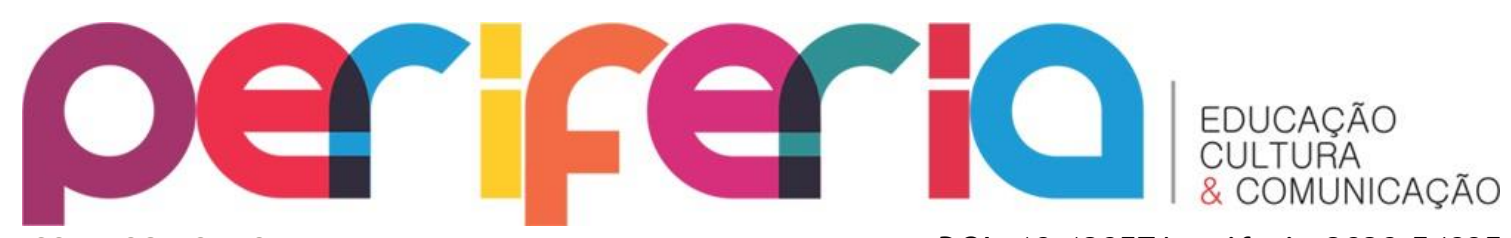

ISSN:1984-9540

DOI: $10.12957 /$ periferia.2020.54835

da Goméia. Ou seja, a referência do terreiro passou a orientar os que o buscavam quando usavam a condução.

Eram também colocados nas paredes dos mercadinhos de Nilópolis, Nova Iguaçu e Duque de Caxias, papéis e cartazes onde se divulgavam os eventos: "Segunda-feira: dia de distribuição de sopas e agasalhos aos pobres; festa para Obaluaê e gira para Exus”. Ou seja, havia um calendário de festas bem definido no terreiro, com eventos para os orixás, danças, homenagens ao caboclo Pedra Preta, festa de saída de iaôs. Devido a essa publicidade estratégica em locais de grande frequência de pessoas, as festas do terreiro eram bastante divulgadas pela população local, sem falar que a mesma estratégia de marketing acontecia nas boates e nos teatros onde Joãozinho se apresentava como bailarino e coreógrafo.

Joãozinho da Goméia transformou seu terreiro em um lugar político com todas as nuances que the cabiam: o conflito, as bajulações e as estratégias de poder que foram materializadas nos espaços onde se alinhavam as redes de sociabilidades, nos espaços de circulação externa (estacionamento, varanda, aldeia dos orixás - onde ficavam os assentamentos de orixás ligados à terra como Obaluaê, Exu, lansã, Oxossi, Tempo) e nos espaços internos: o quarto do jogo, roncó, cozinha do terreiro e as arquibancadas.

Segundo Pereira (2019), era perto da cozinha do terreiro onde eram servidas as comidas ${ }^{38}$. A cozinha dava acesso ao salão onde estava localizado o trono do Rei. À frente do trono ficava a arquibancada com seis degraus, o que nos sugere que era uma forma do pai de santo "controlar, vigiar e punir", ou mesmo "adular" e ser "adulado". O controle da vigilância era o norte da atuação do Rei. Ele precisava observar as arquibancadas, os ogãs, os filhos de santo; tudo, enfim. Observando, ele sabia como agir ao seu favor.

Absolutamente tudo no terreiro foi pensado para ser controlado pelo pai de santo, e assim ele exercia seu poder. Um exemplo disso é a porta do barracão que era igual às barulhentas portas de bar, segundo depoimento de uma filha de santo entrevistada para a tese de doutorado de Rodrigo Pereira: “a porta era grande e

\footnotetext{
${ }^{38} \mathrm{Na}$ tese de Rodrigo Pereira não fica clara esta diferenciação por se tratar da narrativa de uma filha de santo, então fica imprecisa esta informação (PEREIRA, 2019).
}

Periferia, v. 12, n. 3, p. 67-93, set./dez. 2020 


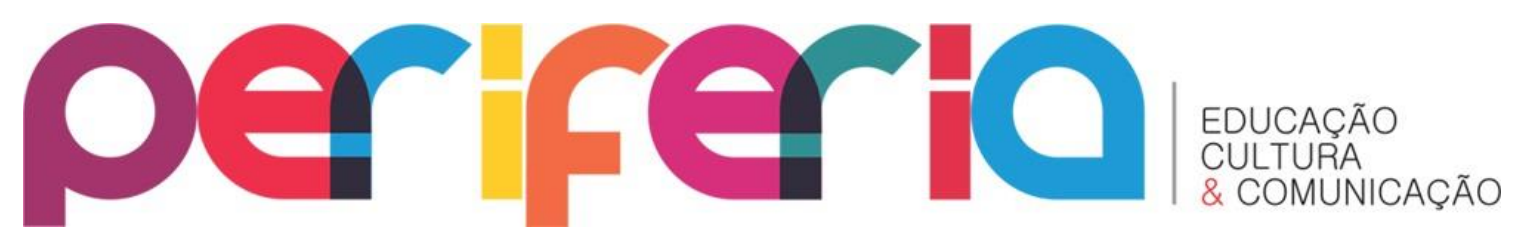

ISSN:1984-9540

DOI: $10.12957 /$ periferia.2020.54835

rangia, toda vez que alguém passava por ali Pai João tomava conhecimento" (PEREIRA, 2019).

Os espaços internos do terreiro eram: quarto de Jogo, o Roncó, o Quarto de Oxalá e lemanjá e o quarto onde se guardavam os assentamentos dos filhos de santo da casa. A mesma filha de santo informa que Joãozinho era tão desregrado que não seguia as normas tradicionalistas de fazer o candomblé, e um dado que aponta isso é relativo ao quarto de jogo dedicado ao jogo de búzios: "ele não jogava pra Exu no horário em que Exu estava mais ativo (de manhã cedinho e no fim da tarde), porque os Nagôs seguem esta regra, bastava chegar e pagar que ele jogava". Este dado aponta que o pai de santo criava suas próprias regras e recriava os ritos ao seu bel prazer de acordo com suas próprias conveniências e necessidades.

O poder do pai de santo ia além da esfera religiosa, sendo a cozinha do terreiro um local onde as iguarias eram preparadas para servir ao público. Segundo um depoimento cedido ao arqueólogo Rodrigo Pereira, “Joãozinho servia comidas e bebidas finas ali durante o toque" quando não estava incorporado dançando no centro do terreiro o público que frequentava era muitas vezes servido pelo próprio pai de santo que com pulso firme controlava a festa (PEREIRA, 2019, p. 383). A cozinha funcionava com carvão, o que era comum para os terreiros dos anos de 1950 e 1960. Tudo se aquecia naquele forno de tijolos - até os banhos das visitas.

A comida servida na Goméia "era de gente rica", que pobre não comia. Segundo Rodrigo Pereira os pobres não podiam comer nada do que ali era servido. A comida levava creme de leite, azeitona. Eram servidas em travessas caras e importadas.

As comidas da Goméia eram refinadas, porque Joãozinho investia todo o dinheiro que ganhava com as apresentações em teatros, boates e festivais na divulgação do seu nome. Ali eram servidos Abará, Acarajé, Arroz branco, Arroz de forno, Arroz-de-hauçá, Bobó, Bolo inglês, Canapés, Canjica de milho branco, Caruru, Churrasco, Empadinhas de camarões, Estrogonofes variados, Farofas, Feijão de leite, Feijoada, Frigideira de camarões, Galinha ao molho pardo, Galinha a cabidela, Mariscada, Maniçoba, Moqueca de peixes, de mariscos, de siri mole, 


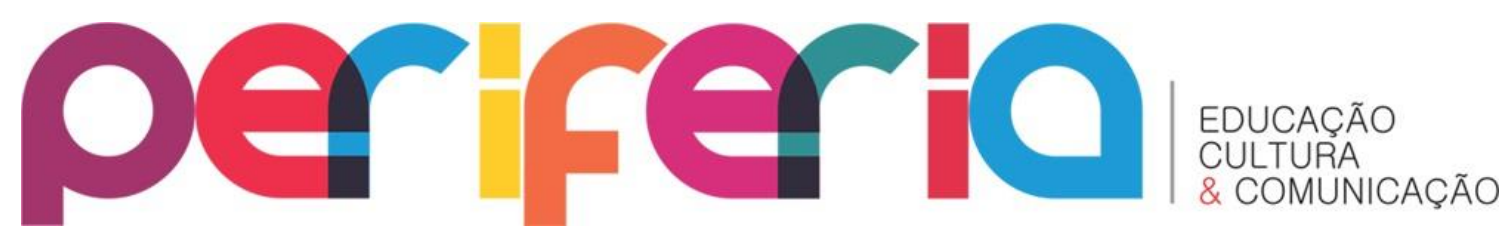

ISSN:1984-9540

DOI: $10.12957 /$ periferia.2020.54835

Moqueca de Xaréu, Pastéis, Pato com laranja, Sarapatel, Vatapá, Xinxim de galinha ${ }^{39}$.

Segundo a reportagem do Diário da Noite de $1950^{40}$, o recolhimento das iaôs da Goméia se dava de 15 a 20 dias. Às 4 da manhã eram banhadas com folhas de mato. Ao meio-dia recebiam alimentação normal que se repetia às 16 horas. Os pratos eram constituídos de manjares vindos da Bahia: camarão, galinha de Angola, canjica de milho branco.

Quando esteve na Gomeia, a atriz Ninon Sevilla provou abará, que é um prato da culinária afro-baiana. É comida de lansã, Obá e Ibeji. Trata-se de um pequeno bolo de massa de feijão fradinho com cebola, sal, azeite de dendê, envolto em folha de bananeira e cozido na água. Às vezes leva camarão inteiro ou moído e misturado na massa (CACCIATORE, 1988). Ganhou uma figa contra o mau olhado e bebeu licor de gengibre. A ideia da visita de Ninon à Goméia surgiu de umas amizades que tinha em Copacabana. Ligou para Joãozinho, que a convidou prontamente. Na porta do terreiro já à espera de Ninon e seus amigos estava Joãozinho da Gomeia, que trajava uma blusa de cor azul clara com dezenas de fios de conta em volta do pescoço; o pai de santo recebeu a comitiva de grã-finos. Ao som frenético dos atabaques, dezenas de mulheres com suas cabeças completamente raspadas faziam evoluções em volta do amplo salão, sob o olhar fascinado da multidão que se comprimia nas arquibancadas e em algumas cadeiras postas especialmente para os convidados ${ }^{41}$. Segue abaixo foto do Última Hora de 1955, que retrata a visita de Ninon Sevilla:

39 Informações retiradas dos depoimentos de Omindarewa, lleci da Oxum, e Sinah Vuru ainda utilizadas em pesquisa de mestrado em andamento.

${ }^{40}$ Diário da Noite, 10 de setembro de 1950

${ }^{41} \mathrm{UH}, 7$ de agosto de 1955.

Periferia, v. 12, n. 3, p. 67-93, set./dez. 2020 


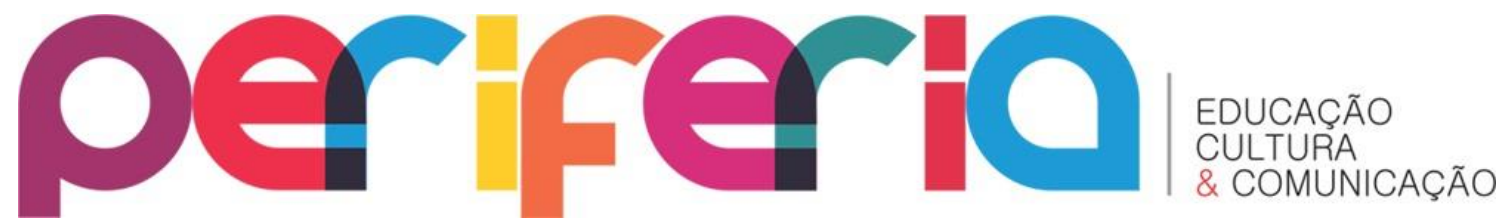

ISSN:1984-9540

DOI: $10.12957 /$ periferia.2020.54835

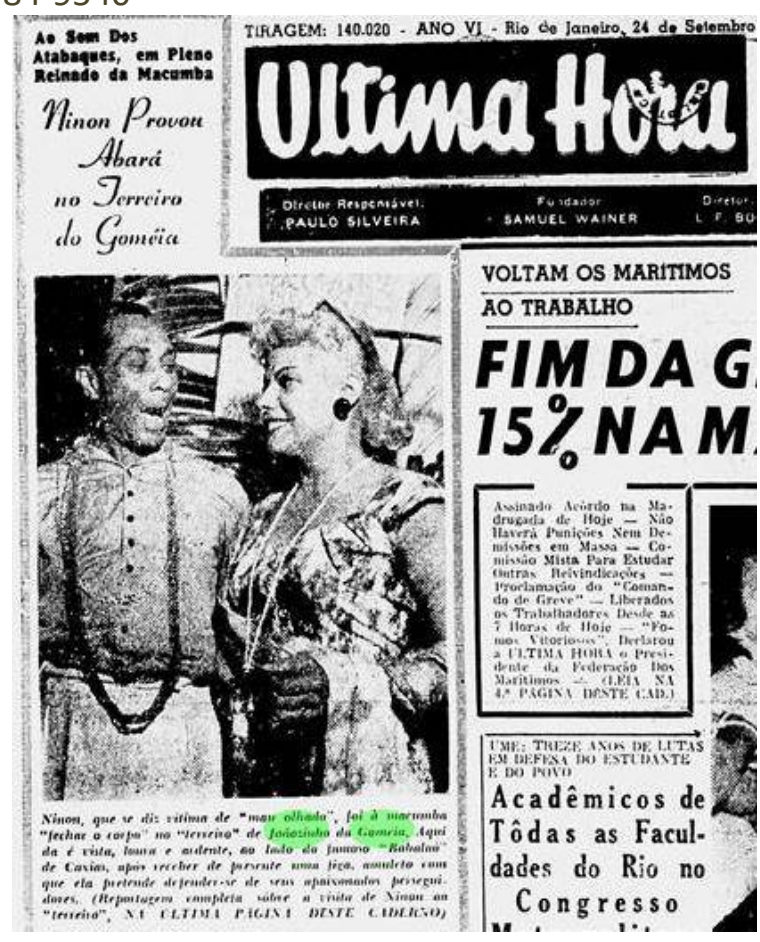

0 povo da Goméia não revela seus fundamentos nem expõe seus rituais secretos. Na busca por saber dos detalhes da culinária de terreiro servida para cada Orixá ainda não foi possível obter informações completas.

Segundo Cacciatore (1988), as comidas de santo são alimentos votivos preparados ritualmente e oferecidos aos Orixás, os quais necessitam de suas vibrações para manutenção da própria força dinâmica. Algumas comidas são preparadas com a carne dos animais sacrificados ritualmente, outras com peixe, camarão, verduras, ervas, farinhas, etc. muitas bem temperadas com cebola, sal, pimenta, mel, azeite doce, azeite de dendê.

A antropóloga Giselle Binon Cossard me informou que trouxe muitas louças, talheres, travessas e panos de mesa da França. Que quando viajava para a Europa, Joãozinho já aparecia com uma lista enorme de pedidos para "cama, mesa e banho", além dos tecidos que eram trazidos do Benin e Marrocos. 


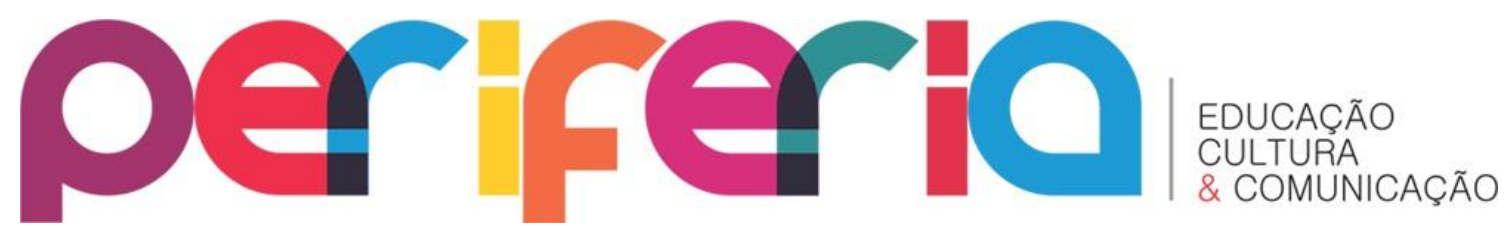

ISSN:1984-9540

DOI: $10.12957 /$ periferia. 2020.54835

0 cruzamento ${ }^{42}$ das fontes feitas para este artigo mostrava que Joãozinho buscava o requinte como uma moeda de troca para receber suas visitas. 0 "fogo da Goméia" era ativado no fogão a lenha já que naquela época o fogão a lenha era mais barato.

Segundo o arqueólogo Rodrigo Pereira o estacionamento permitia que os visitantes "motorizados" deixassem ali seus veículos. ${ }^{43}$ Joãozinho também deixava que pessoas das redondezas guardassem ali seus veículos, desde que respeitassem os espaços sagrados do terreiro e da casa do pai de santo. 0 estacionamento servia para separar as visitas famosas e "ilustres" das visitas sem prestigio.

A casa de Joãozinho ficava na frente do terreiro, entre o estacionamento e a varanda, onde o pai de santo recebia suas visitas íntimas, e aqueles que poderiam the oferecer algo, como artistas famosos e políticos de renome. A mãe criadeira da Goméia lleci da Oxum contou que o ex-deputado Tenório Cavalcanti era presença constante na varanda de Joãozinho:

(...) O Tenório Cavalcanti sempre visitava a casa e a varanda de Pai João, os dois eram muito amigos. Ali Joãozinho jogava e reforçava as seguranças espirituais do Seu Tenório. Como a varanda ficava perto do estacionamento ninguém via. A não ser nós que éramos próximas de Pai João.

O Última Hora de 21 de janeiro de 1955 fala do prestigio de Joãozinho como um fato comprovado, e que adquiriu o respeito em todos os terreiros com uma fama que corria o país de norte a sul. Os frequentadores da Goméia pertenciam a distintas classes sociais: "ao lado da granfina estava a custureirinha do subúrbio; a empregada do comercio e a domestica. Junto ao aristocrata que chega ao terreiro 'entronados nos cadilacs' estavam o homem da rua; o modesto servidor público e o trabalhador braçal." 44

\footnotetext{
${ }^{42}$ Entrevistas coletadas por Rodrigo Pereira em sua tese de doutorado ${ }^{42}$, quanto às entrevistas coletadas por mim entre 2001 e 2003 e os jornais da Biblioteca Nacional, do Centro Nacional de Folclore e Cultura Popular e do CPDOC.

${ }^{43}$ PEREIRA, Rodrigo. Analise do espaço e da cultira material no extinto terreiro da Goméia (Duque de (axias): um estudo Etnoarqueologico, p. 257.

${ }^{44}$ Última Hora, 21 de janeiro de 1952
}

Periferia, v. 12, n. 3, p. 67-93, set./dez. 2020 


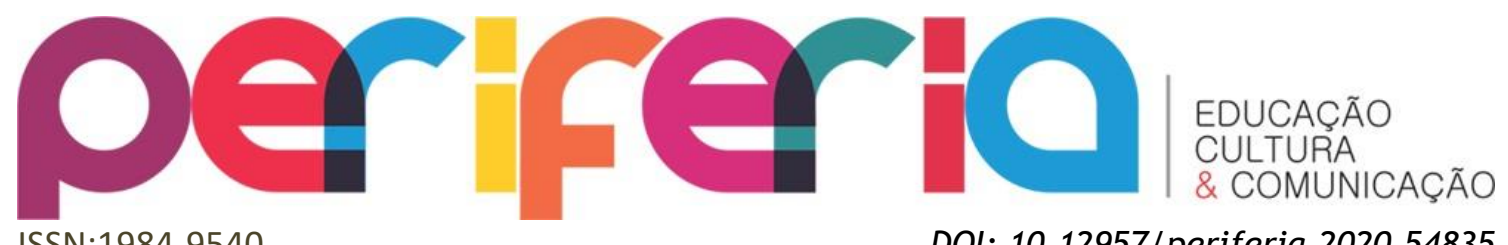

ISSN:1984-9540

DOI: $10.12957 /$ periferia.2020.54835

O Café-soçaite na macumba: Quero ir embora para a Goméia lá sou amigo do Rei.

Segundo uma pesquisa realizada por Leo Feijó e por Marcus Wagner para o livro Rio cultura da noite (FEIJÓ; WAGNER, 2014) o desaparecimento dos cassinos em 1946 estimulou o surgimento de um novo eixo de diversão na zona sul do Rio de Janeiro, frequentado por "uma nova classe que ficou conhecida pelo nome de café soçaite". Eram os grã-finos boêmios que viviam intensamente os prazeres da noite carioca. De acordo com Feijó e Wagner o termo foi criado pela colunista americana Elza Maxwell que misturou os termos café + grana + sociedade. A expressão passou então a traduzir um novo estilo de vida marcado pelas diversões, pela beleza e pelo requinte das roupas luxuosas e da organização dos grandes jantares. Foi também esta parcela divertida da sociedade que até 1946 frequentava os cassinos atrás de banquetes regados a muita bebida, comida e cigarretes importados.

Quando Joãozinho começou a se apresentar no teatro João Caetano nos anos 1950, e em 1960 na boate Fred's, teve contato com a grã-finagem do Café Soçaite, e pôde divulgar seu candomblé nos locais que frequentavam. 0 jornal Diário de Notícias de 1962 lança uma notinha na coluna social informando que toda tarde de apresentação na boate, Joãozinho levava uma iguaria para que as vedetes se alimentassem: “Joãozinho da Goméia agradou mesmo a todos. Toda a noite levava iguarias do seu terreiro para agradar: salgadinhos, doces, bolos etc." 45

Em reportagem da Tribuna da Imprensa de 1952, intitulada Joãozinho da Goméia recebe a sociedade, enumera-se as figuras dos circuitos oficiais, políticos, sociais e diplomáticos que foram a Goméia no dia anterior. Entre as personalidades convidadas estavam mais de cinquenta automóveis, entre elas estavam o coronel Santa Rosa que representava o prefeito João Carlos Vital; o cônsul geral do Canadá e senhora. O deputado Aris Maron e senhora. O almirante Matoso e senhora. 0 deputado Oliveira Brito. O almirante Heat. O chefe da missão naval norteamericana e senhora e o Sr. Paulo Pereira Leitte e senhora. A festividade foi considerada como um dos maiores acontecimentos do candomblé. ${ }^{46}$

\footnotetext{
45 Diário de Notícias, 8 de outubro de 1962.

46 Tribuna da Imprensa, 18 de agosto de 1952
}

Periferia, v. 12, n. 3, p. 67-93, set./dez. 2020 


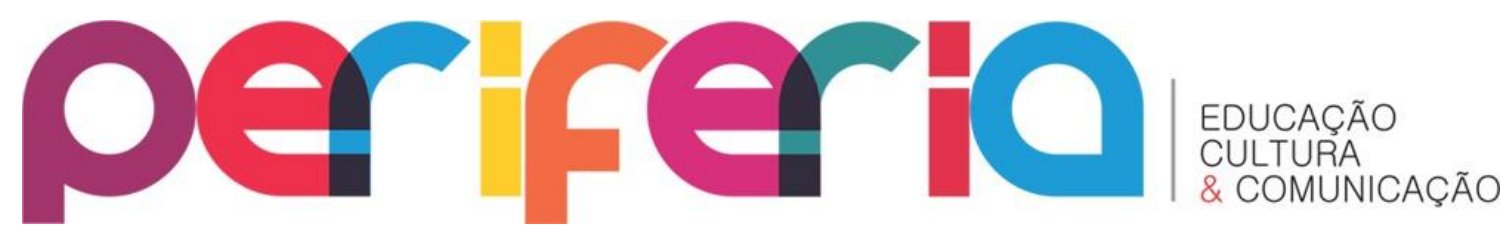

ISSN:1984-9540

DOI: $10.12957 /$ periferia.2020.54835

A fama do pai de santo foi mais uma vez confirmada. Nas festas, quando do inicio dos festejos em louvor a lansã, o terreiro ficava pequeno para acomodar o grande número de pessoas que lotavam todas as dependências. Os batuques só paravam pela madrugada. Quando lansã ia embora, o pai de santo recepcionava os convidados endinheirados. Os festejos só se encerravam dias depois.

0 interessante é perceber que existia uma distinção de tratamento para ricos e pobres no terreiro, ou seja, os alimentos e as bebidas que eram servidos aos ricos e a classe média não eram servidos aos pobres e filhos de santo da casa. 0 alimento, então, desempenha uma função social que está relegada ao campo das estratégias e das negociações criadas pelo pai de santo para obter trânsito por lugares onde um homem negro e "macumbeiro" jamais circularia. ${ }^{47}$ Os banquetes da Goméia se transformaram de certa forma em um cartão de visita que comporia a estrutura das festas e da estética do terreiro, formando uma tríade que atraía consulentes, visitantes e convidados, que fizeram da Goméia o que ela foi de 1949 a 1971.

Em 1952, Joãozinho da Goméia aparece na imprensa como um símbolo de afro-brasilidade ao ser escolhido pelo presidente Getúlio Vargas para se apresentar com suas filhas de santo em uma grande recepção no Largo do Boticário à Dean Acheson - o secretário de Estado dos Estados Unidos. Nesta recepção estavam o diretor do jornal O Globo, Roberto Marinho, a senhora Darcy Vargas, o ministro Negrão de Lima; a senhora João Neves de Fontoura; o ministro Renato Guilhobel; a senhora Horácio Lafer; o ministro João Cleofas; a senhora Lourival Fontes; o vicepresidente Café Filho; a senhora Souza Lima; os ministros Ciro E. Santo Cardoso e Simões Filho; e o Presidente da República Getúlio Vargas.

Joãozinho na ocasião ofereceu a Dean Acheson e Senhora uma boneca vestida de baiana como símbolo de sorte.

$47 \mathrm{O}$ termo macumbeiro foi usado pela historiadora Elizabeth Gama em sua dissertação de mestrado (GAMA, 2014).

Periferia, v. 12, n. 3, p. 67-93, set./dez. 2020 


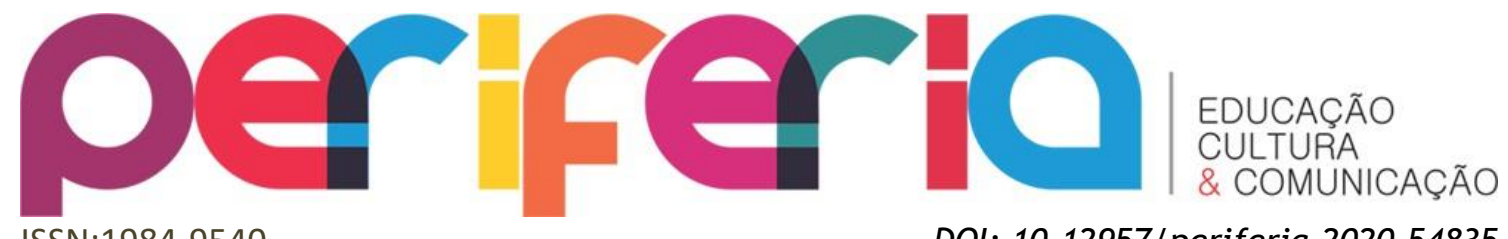

ISSN:1984-9540

DOI: $10.12957 /$ periferia. 2020.54835
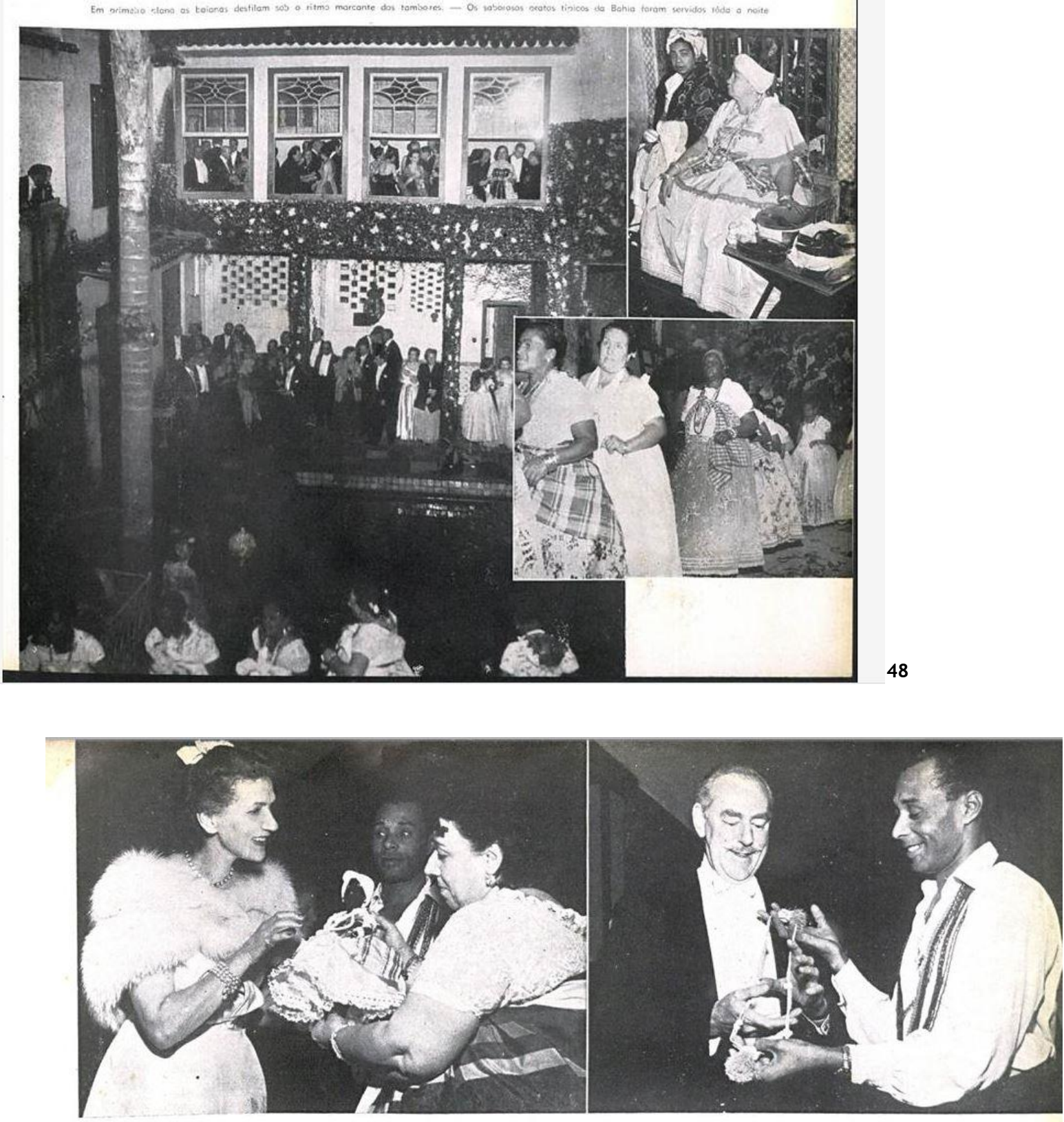

Uma boneca é oferecida à senhora Dean Acheson, como simbolo de boa-sorte Joãosinho da Goméia oferece ao sr. Acheson um fetiche

${ }^{48}$ Revista Rio, julho de 1952.

Periferia, v. 12, n. 3, p. 67-93, set./dez. 2020 

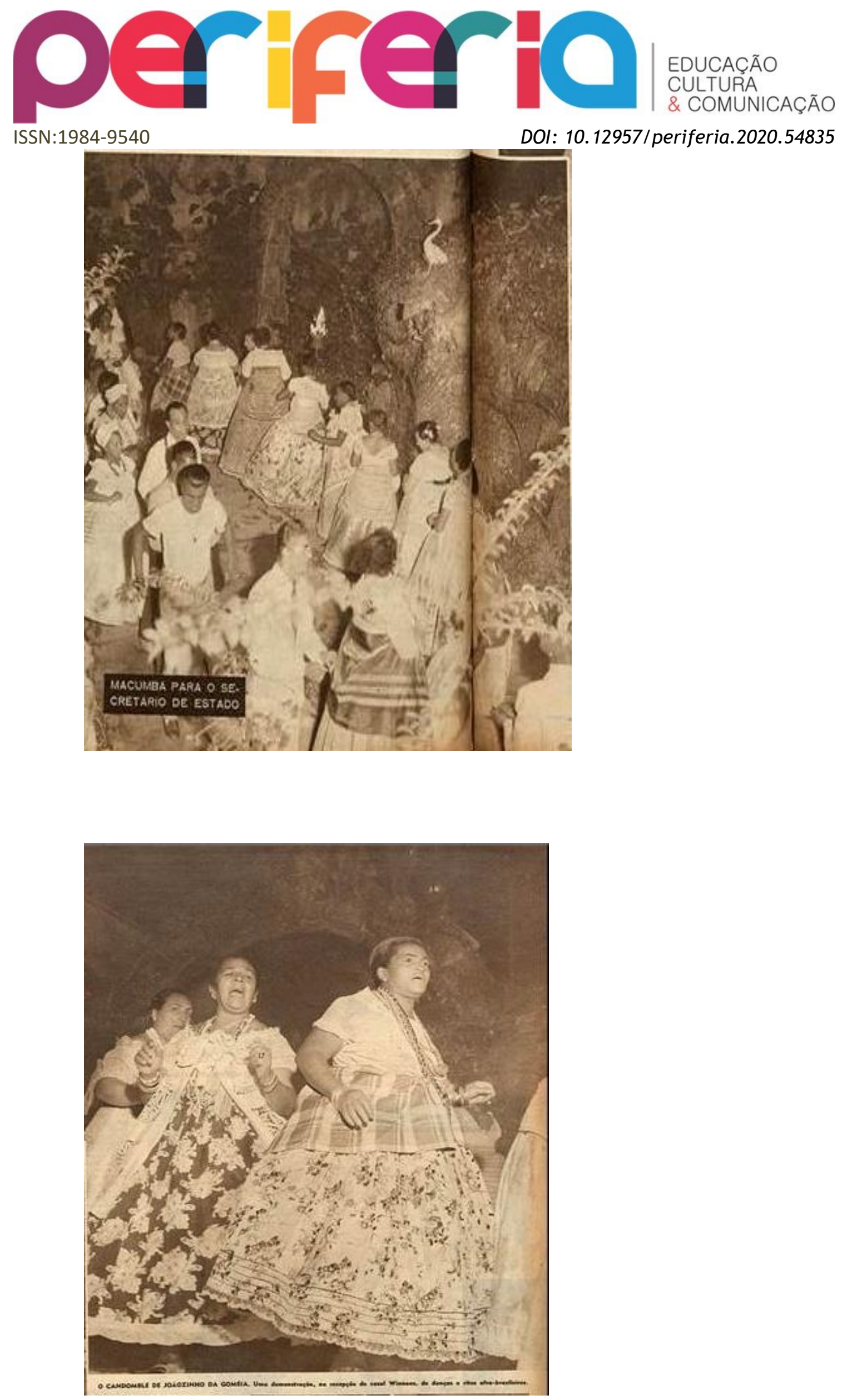

Periferia, v. 12, n. 3, p. 67-93, set./dez. 2020 


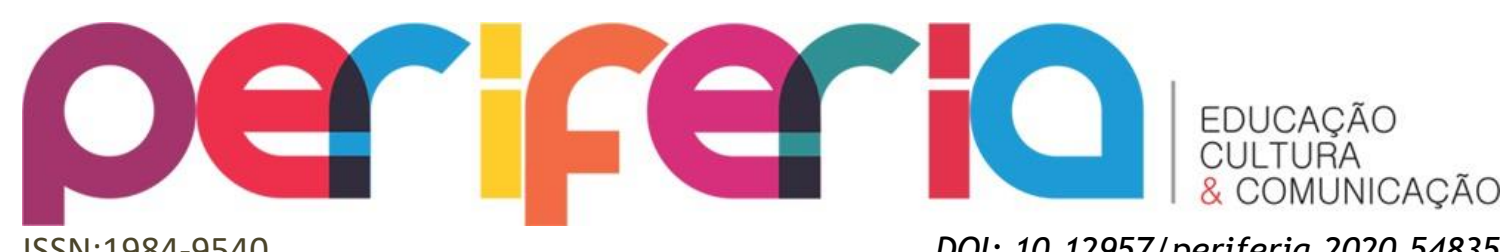

ISSN:1984-9540

DOI: 10.12957/periferia.2020.54835

\section{Considerações finais}

Explicitamos neste artigo como as festas nos terreiros da Goméia do bairro de São Caetano (Salvador) e do município de Duque de Caxias na Baixada Fluminense colaboraram com a construção do status e do prestigio de Joãozinho da Goméia. Para esta análise usou-se uma minuciosa consulta ao material de imprensa, à bibliografia especializada no tema e às entrevistas realizadas com lideranças do candomblé entre 2001 e 2003. O cruzamento destas fontes possibilitou a escrita deste artigo, que faz parte de um dos capítulos da dissertação de mestrado onde investigo como o pai de santo João da Pedra Preta foi transformado pela imprensa em Rei do candomblé entre 1936 e 1952.

\section{REFERÊNCIAS}

AMADO, JORGE. Bahia de todos os santos: guia de ruas e mistérios. Rio de janeiro, Record, 1991.

BASTIDE, Roger. Imagens do nordeste místico em branco e preto. Seção de livros da Empresa gráfica "O Cruzeiro" S.A. Rio de Janeiro, 1945.

BRAGA, Júlio. Na gamela do feitiço: repressão e resistência nos candomblés da Bahia, p. 95. Salvador: EDUFBA, 1995.

CACCIATORE, Olga Gudolle. Dicionário de cultos afro-brasileiros. RJ: Forense Universitária editora, 1988.

CARNEIRO, Edson. Religiões negras; notas de etnografia religiosa; Negros bantos: notas de etnografia religiosa e de folclore. Civilização brasileira, RJ: 1938-1 ${ }^{\text {a }}$ edição.

FEIJÓ, Leo e WAGNER, Marcus. Rio cultura da noite-uma historia da noite carioca. RJ: Casa da palavra produção editorial, 2014.

GAMA, Elisabeth Castelano. Mulato, homossexual e macumbeiro: que rei é este? Trajetoria de João da Goméia(1914-1971). APPH-Clio, Duque de Caxias. Série Recôncavo da Guanabara, volume 2, 2014.

LODY, Raul e SILVA, Vagner Gonçalves da. Joãozinho da Goméia: o lúdico e o sagrado na exaltação ao candomblé. IN: Caminhos da alma: memória afrobrasileira. SP: Summus, 2002.

Periferia, v. 12, n. 3, p. 67-93, set./dez. 2020 


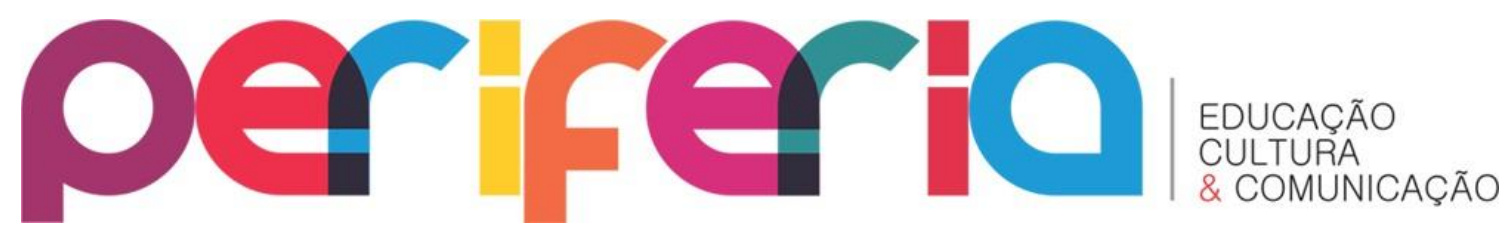

ISSN:1984-9540

DOI: 10.12957/periferia.2020.54835

NASCIMENTO, Andréa dos Santos. De São Caetano a Caxias: um estudo de caso sobre a trajetória do Rei do Candomblé Joãozinho da Goméia. Monografia de graduação em historia. SG: UERJ, 2003.

PEREIRA, Rodrigo. Análise do espaço e da cultura material no extinto terreiro da gomeia (Duque de Caxias): um estudo etnoarqueológico. RJ: Tese de Doutorado defendida pelo Museu Nacional da UFRJ, 2019.

RAMOS, Arthur. O folclore negro do Brasil: demopsicologia e psicanálise. $3^{\text {a }}$ ed. SP: WMF Martins Fontes, 2007.

\section{FONTES:}

A Manhã, 13/02/1949

A Cena muda de 5 de julho de 1949

Correio da Manhã de 21 de dezembro de 1953

Diário da noite, 18 de agosto de 1952

Diário da Noite, 14 de setembro de 1949

Diário da noite, 10 de setembro de 1950

Diário de noticias de 8 de outubro de 1962.

Revista Rio, julho de 1952

Tribuna da Imprensa de 18 de agosto de 1952

Última Hora, 21 de janeiro de 1952

Periferia, v. 12, n. 3, p. 67-93, set./dez. 2020 